$I 19.2: W 99 / 2 / 975-76$

\title{
WATER-RESOURCES INVESTIGATIONS OF THE U. S. GEOLOGICAL SURVEY IN THE MAJOR COAL AND OIL SHALE AREAS OF WYOMING, 1975-76
}

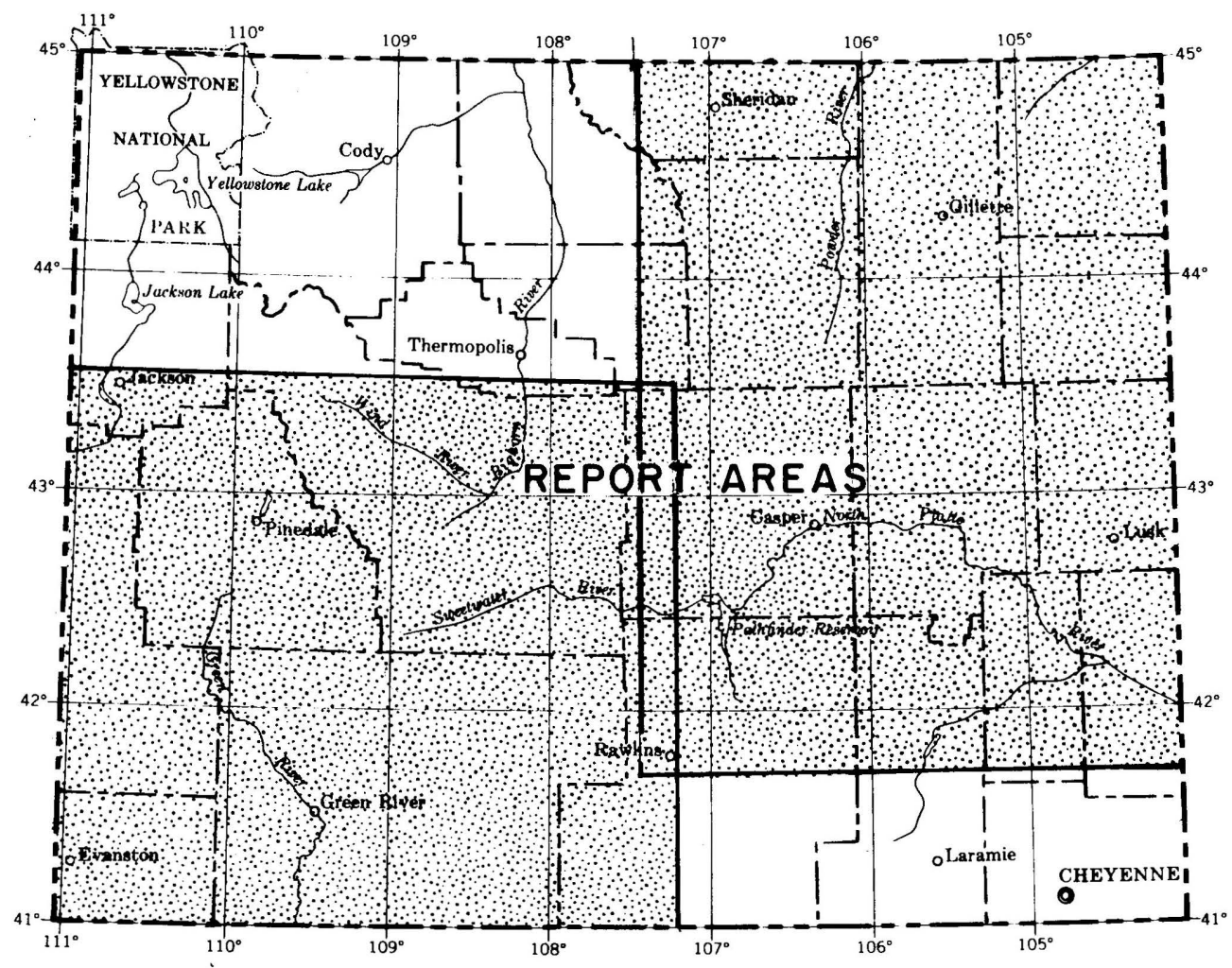

Prepared by

UNITED STATES DEPARTMENT OF THE INTERIOR GEOLOGICAL SURVEY

OPEN FILE REPORT

JANUARY 1976

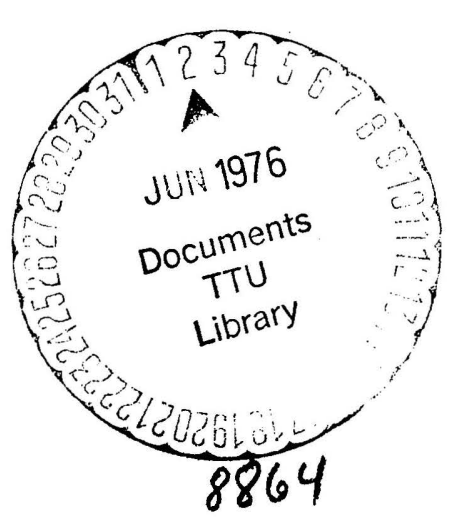





\section{UNITED STATES \\ DEPARTMENT OF THE INTERIOR \\ GEOLOGICAL SURVEY}

WATER-RESOURCES INVESTIGATIONS OF THE

U.S. GEOLOGICAL SURVEY IN THE

MAJOR COAL AND OIL SHALE AREAS

OF WYOMING, 1975-76

By U.S. Geological Survey, Water Resources Division

Open-File Report 


\section{UNITED STATES DEPARTMENT OF THE INTERIOR \\ Thomas S. Kleppe, Secretary \\ GEOLOGICAL SURVEY \\ V. E. McKelvey, Director}

COOPERATING AGENCIES

State Agencies

Wyoming Department of Agriculture

Wyoming Department of Economic Planning and Development

Wyoming Department of Environmental Quality

Wyoming Highway Department

Wyoming State Engineers

\section{Federal Agencies}

Bureau of Land Management

Bureau of Reclamation

Environmental Protection Agency

old West Regional Commission 
Introduction-

Data-collection activities-_-

Streamflow and reservoir stations

Crest-stage stations-_-

Chemical-quality stations-

Sediment stations-

Observation wells

Water-resources appraisal projects-_

Water resources of Weston County, Wyoming-

Measurement of water losses to the Madison

Limestone and associated rocks from streams

in northeastern Wyoming

Water and its relation to economic development

in the Green River and Great Divide basins in Wyoming--

Impacts of economic development and water use on water

resources in the Hanna basin in Wyoming

Water resources of the Powder River structural

basin in Wyoming in relation to energy development--

Hydrology of Paleozoic rocks in the Powder River basin and adjacent areas, northeastern Wyoming-_- 34

Algal growth potential of principal North Platte River reservoirs in Wyoming-_-

Availability of ground water from the Cretaceous and

Tertiary aquifers of the Fort Union Coal Region--_-_-- 35

Geochemical survey of waters of the western coal regions------ 36

Channel changes in the Powder River-_- 36

Red Rim EMRIA study site near Rawlins, Wyoming-_-_-_-_ 36

Potter Mountain EMRIA study site near Rock

Springs, Wyoming-_ 37

Sediment yield estimates, Campbell County, Wyoming-- 38

Sorption of residual organic substances in retort

waters by spent oll shale residues- 38

Selected references- 40 
Page

Figures 1-10. Maps showing locations of:

1. Streamflow and reservoir stations in the

Powder River structural basin-_- 3

2. Streamflow and reservoir stations in the Green

River, Bear River, and Great Divide basins-_-_-_- 4

3. Crest-stage stations in the Powder River structural basin- 9

4. Crest-stage stations in the Green River and Great Divide basins-_- 10

5. Chemical-quality stations in the Powder River structural basin-_-_- 14

6. Chemical-quality stations in the Green River, Bear River, and Great Divide basins-_- 15

7. Sediment stations in the Powder River structural basin-- 21

8. Sediment stations in the Green River, Bear River, and Great Divide basins- 22

9. Observation wells in the Powder River structural basin--_- 26

10. Observation wells in the Green River, Bear River, and Great Divide basins-_ 27

TABLES

Page

Table 1. Streamflow and reservoir stations- 6

2. Crest-stage stations-_ 12

3. Chemical-quality stations- 17

4. Sediment stations-_- 24

5. Observation wells- 29. 


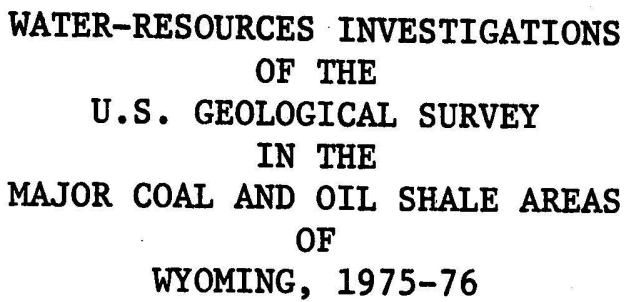

\section{INTRODUCTION}

The U.S. Geological Survey, in cooperation with the State of Wyoming and other Federal agencies, has five data-collection activities and fourteen water-resource appraisal projects in the major coal and oil shale areas of Wyoming. These activities are located primarily in the Northern Great Plains coal region of northeastern Wyoming (the Powder River structural basin) and the Green River, Bear River, and Great Divide basins of southwestern Wyoming.

The data-collection activities include: (1) Continuous records of streamflow and reservoir storage; (2) peak flow information at partialrecord sites; (3) sampling and chemical analyses of water from streams and wells; (4) sampling and sediment analysis of water from streams; and (5) measurements of water levels in wells. This report contains lists of monitoring sites for these five data-collection activities.

The water-resource appraisal projects include: (1) Water Resources of Weston County, Wyoming; (2) Measurement of Water Losses to the Madison Limestone and Associated Rocks from Streams in Northeastern Wyoming;

(3) Water and Its Relation to Economic Development in the Green River and Great Divide Basins in Wyoming; (4) Impacts of Economic Development and Water Use on Water Resources in the Hanna Basin in Wyoming; (5) Water Resources of the Powder River Structural Basin in Wyoming in Relation to Energy Development; (6) Hydrology of Paleozoic Rocks in the Powder River Basin and Adjacent Areas, Northeastern Wyoming; (7) Algal Growth Potential of Principal North Platte River Reservoirs in Wyoming; (8) Availability of Ground Water from the Cretaceous and Tertiary Aquifers of the Fort Union Coal Region; (9) Geochemical Survey of Waters of the Western Coal Regions; (10) Channel Changes in the Powder River; (11) Red Rim EMRIA Study Site Near Rawlins, Wyoming; (12) Potter Mountain EMRIA Study Site Near Rock Springs, Wyoming; (13) Sediment Yield Estimates, Campbell County, Wyoming; and (14) Sorption of Residual Organic Substances in Retort Waters by Spent 0il Shale Residues. The objectives of these projects are described later in this report.

The purpose of this report is to describe what is being done in the coal and oil shale development areas in Wyoming. It is one phase of an effort to coordinate the water resources investigations of the U.S. Geological Survey with those of other organizations. Additional information about the water resources program of the Geological Survey or closer coordination of the water-resources studies may be obtained by contacting the District Chief, Water Resources Division, U.S. Geological Survey, 4015 Warren Avenue, P.0. Box 2087, Cheyenne, Wyoming. The commercial telephone number is 307-778-2220, extenstion 2111, and the FTS number is 328-2111. 
Basic data are currently being collected at sites tabulated in the following tables: (1) Streamflow and Reservoir Stations; (2) Crest-Stage Stations; (3) Chemical-Quality Stations; (4) Sediment Stations; and (5) Observation Wells.

Stations in the first four tables are listed in downstream order. Identification numbers have been assigned to conform with the standard downstream order for listing stations within each hydrologic region.

Observation wells are listed in numerical order by counties. The well-numbering procedure used is based on the U.S. Land Grant System. The first segment of the number is the township (north); the second number segment is the range (west); the third number segment is the section, which is followed by a first letter designating the quarter section, a second letter, if shown, designating the quarter-quarter section, etc.,

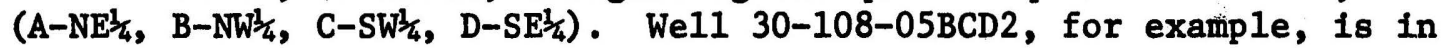

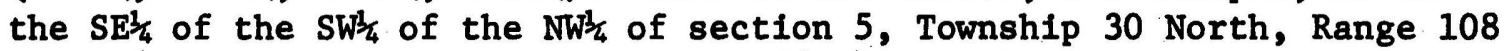
West. The number 2 indicates a second well in the quarter-quarter-quarter section.

The headings of the columns in the five tables are similar but are slightly different to accommodate the type of site in each 1ist. In order to include the variety of information required by the many users of the lists, abbreviations and codes were used to conserve space in the tables. Explanations of the abbreviations and codes are given preceeding each table. 



\section{EXPLANATION}

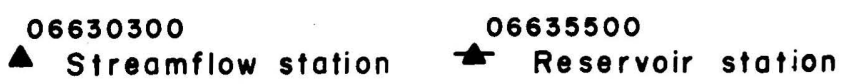

Figure 1.-Streamflow and reservoir stations in the Powder River structural basin. 


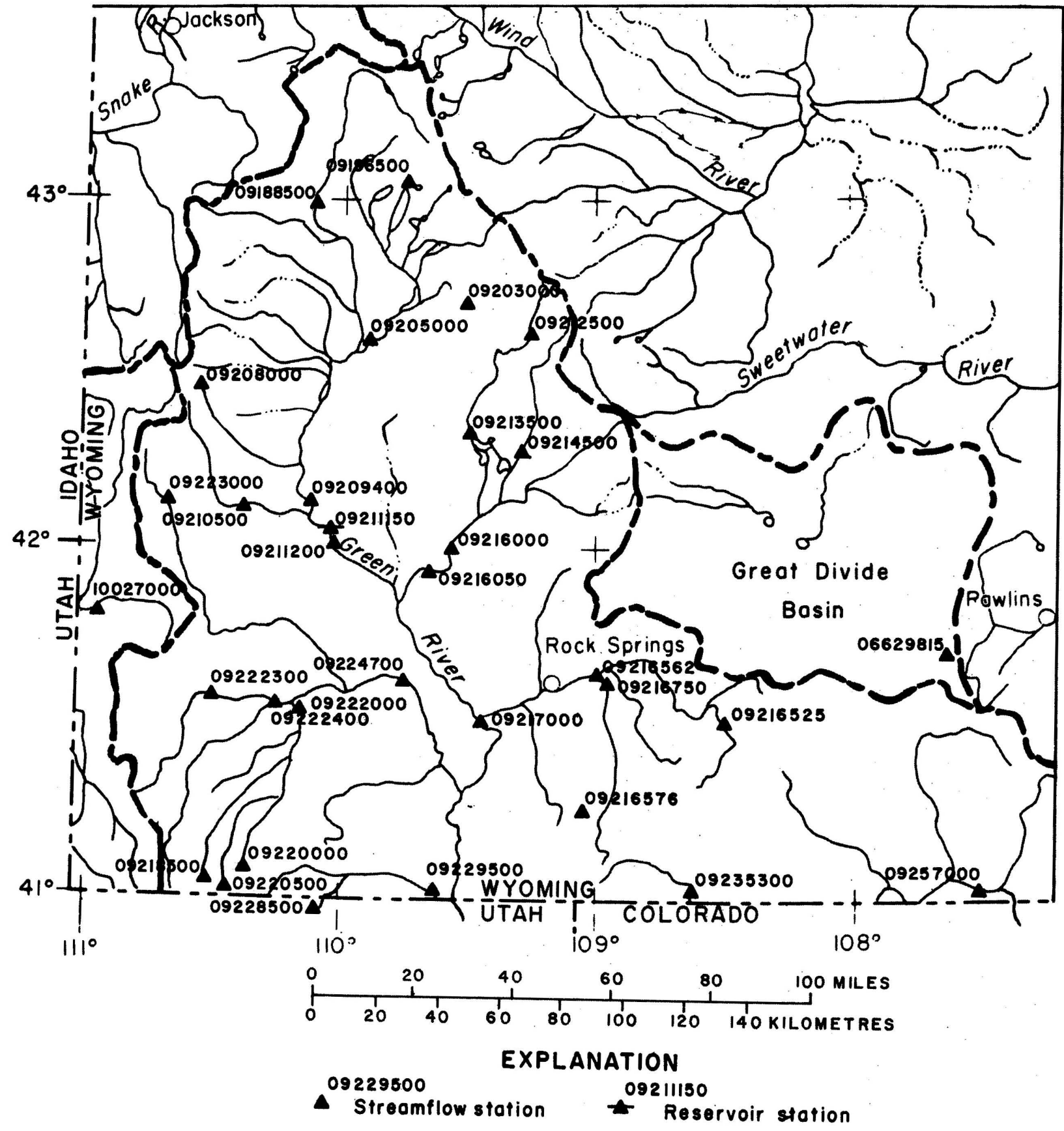

Figure 2.-Streamflow and reservoir stations in the Green River, Bear River, and Great Divide basins. 
Explanation of abbreviations and codes used in table 1 .

Purpose: B, bench-mark or long-term-trend station

$C$, current-purpose station such as accounting, operation, forecasting, disposal, water quality, compact or legal, research or special study.

$\mathrm{H}$, hydrologic station

$P$, principal-stream station

$R$, regulated station

Period of Record: The dates given are the calendar years in which records began or ended. Breaks of less than a year are not shown.

Gage Equipment: D, digital recorder

G, graphic recorder

$M$, manometer gage

$\mathrm{W}$, we11 gage

$T$, pressure-transducer gage

Current Record Type: S, seasonal operation

Y, full-year operation

Field Office: C, Casper

$\mathrm{CH}$, Cheyenne

$R$, Riverton

$\mathrm{W}$, Worland

$S$, Wyoming State Engineer

$M$, Montana district

SD, South Dakota district

Cooperator: BLM, Bureau of Land Management

BRUC, Bureau of Reclamation, Upper Colorado Region

BRUM, Bureau of Reclamation, Upper Missour 1 Region

DEPD, Wyoming Department of Economic Planning and Development

MRB, Missouri River basin project

USGS, Geological Survey--Federal Program

WSE, Wyoming State Engineer

028, Madison Recharge Project--Wyoming State Engineer 
Table 1. Streamflow and Reservoir Stations

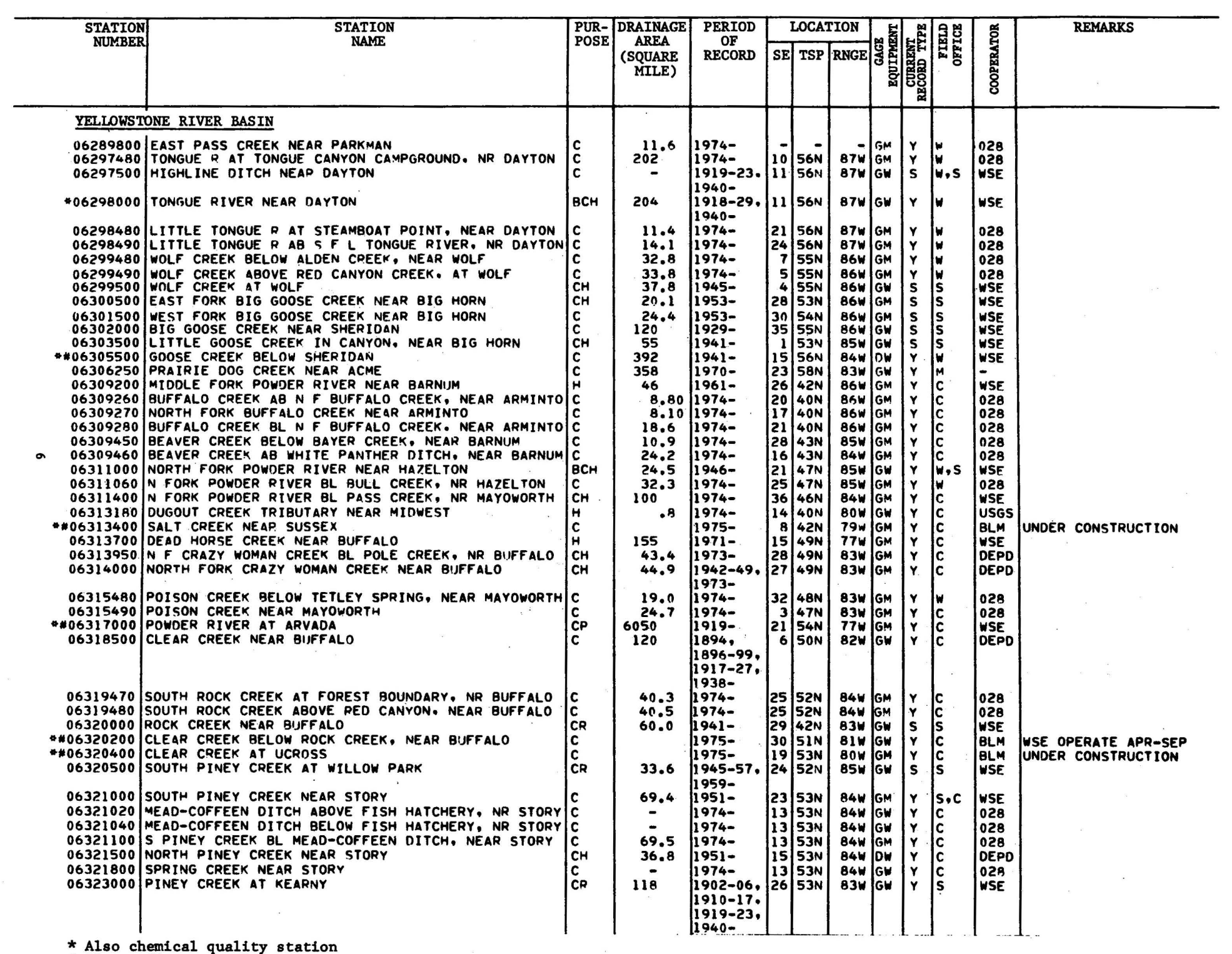

* Also chemical quality station
\# Also sediment station 
Table 1. Streamflow and Reservoir Stations (Continued)

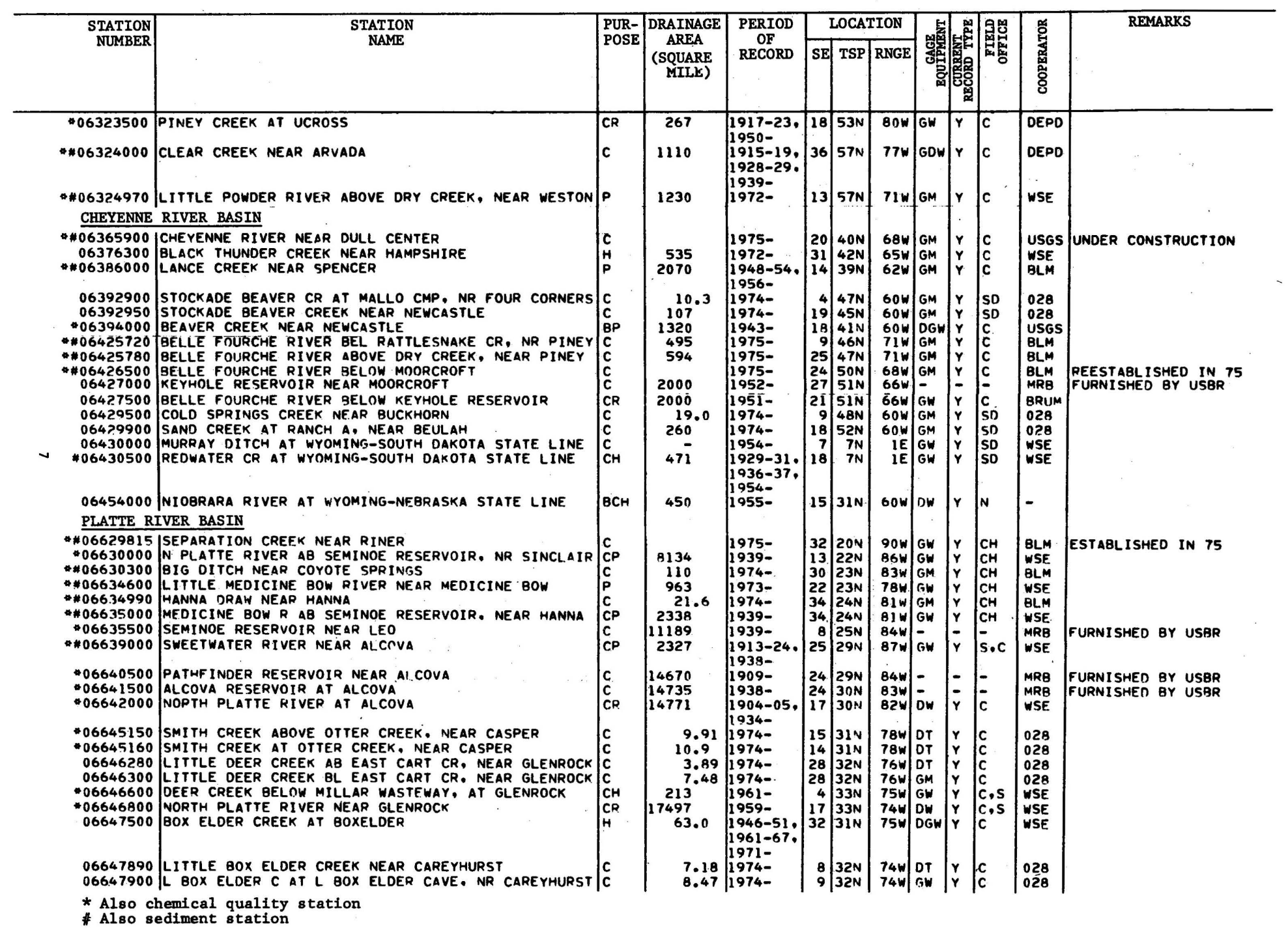


Table 1. Streamflow and Reservoir Stations (Continued)



* Also chemical quality station

\# Also sediment station 


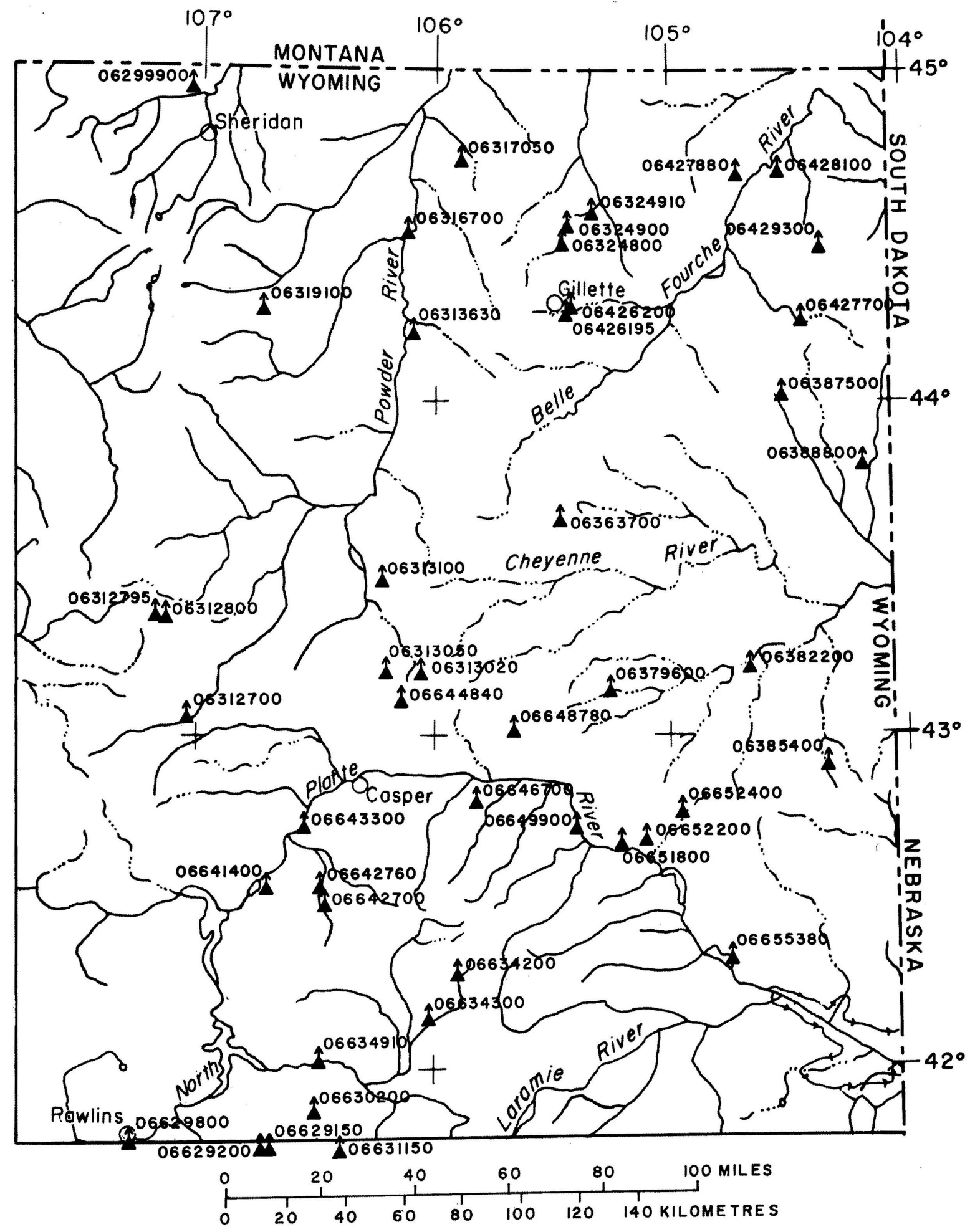

Figure 3.-Crest-stage stations in the

Powder River structural basin. 


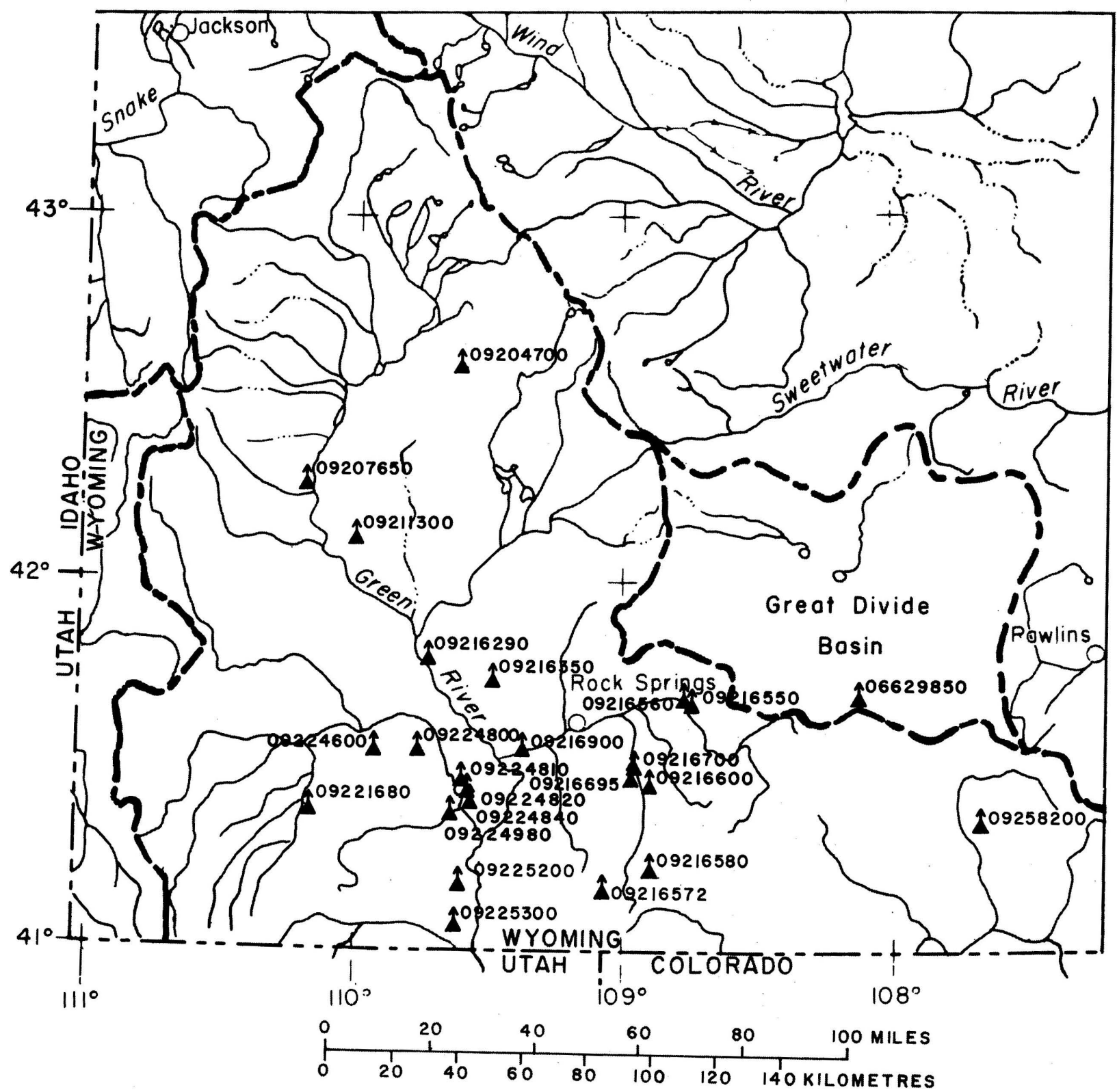

Figure 4.-Crest-stage stations in the Green River and Great Divide basins. 
Explanation of abbreviations and codes used in table 2.

Period of Record: The dates given are the calendar years in which records bega began or ended. Breaks of less than a year are not shown.

Gage Equipment: CSI, crest-stage indicator

$S-R$, stage-rainfall recorder

Field Office: W, Worland

C, Casper

$\mathrm{CH}$, Cheyenne

$R$, Riverton

Cooperator: BLM, Bureau of Land Management

WHD, Wyoming Highway Department 
Table 2. Crest-Stage Stations

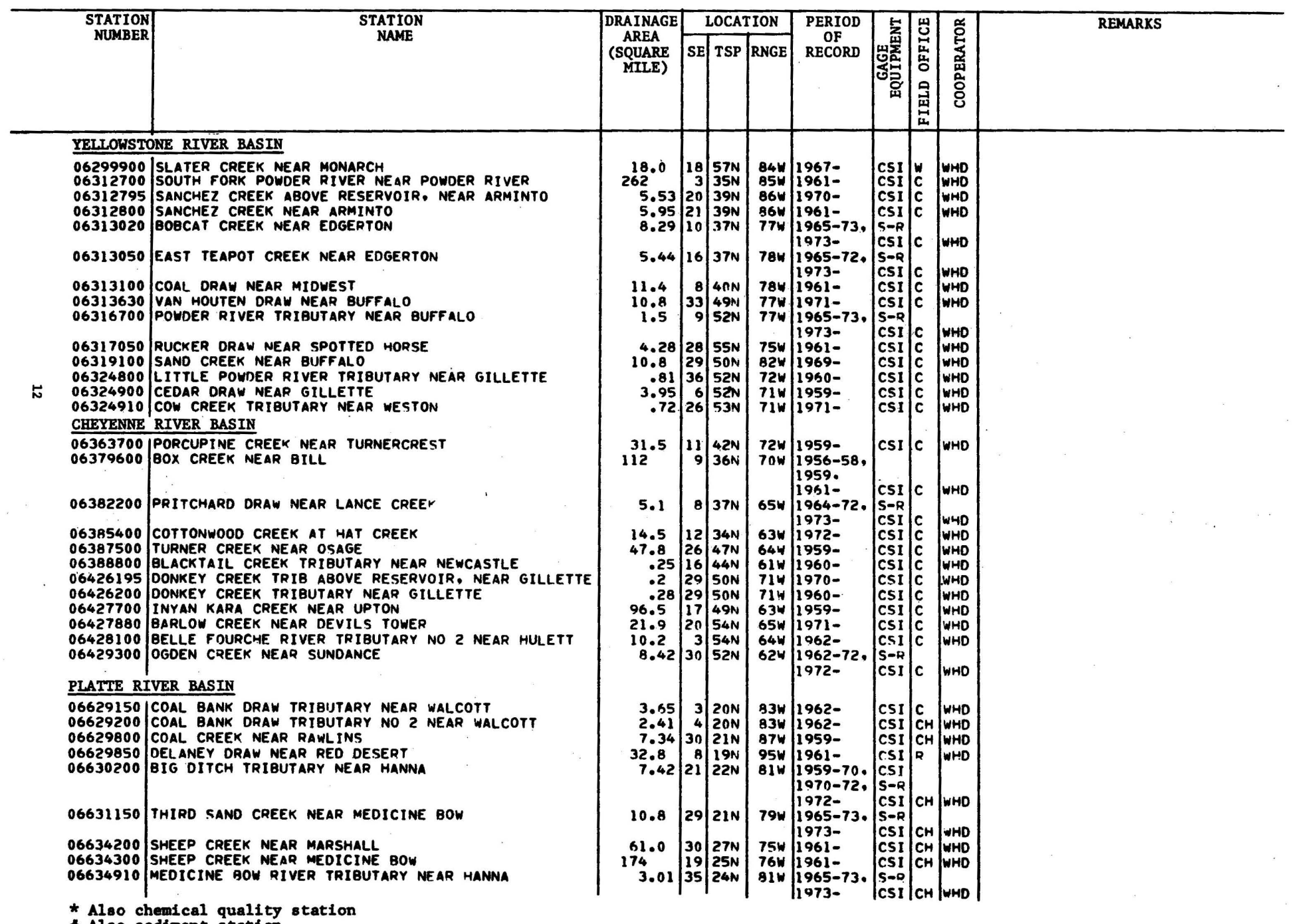

* Also chemical quality station 
Table 2. Crest-Stage Stations (Continued)

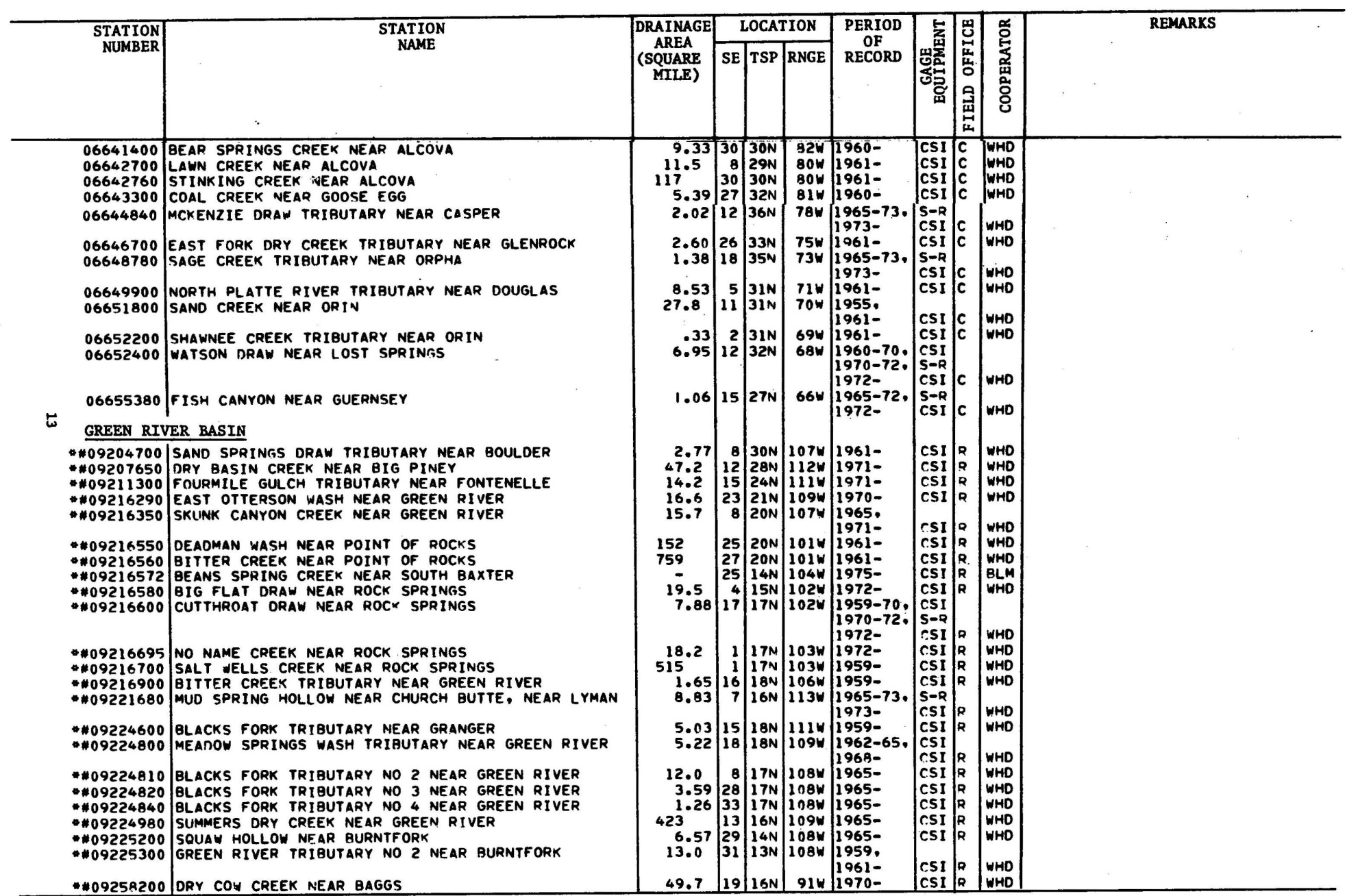

* Also sediment station 


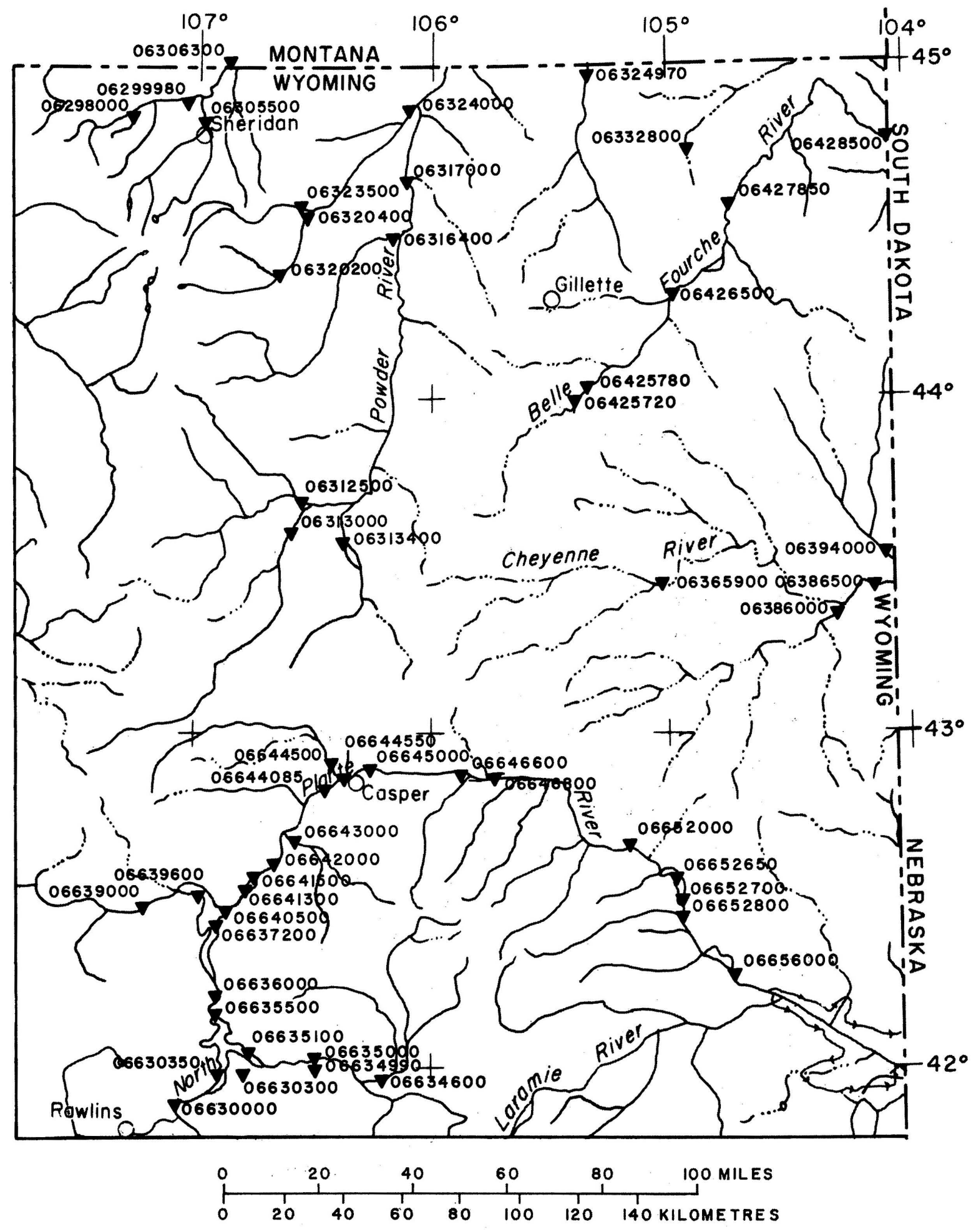

Figure 5.-Chemical-quality stations in the

Powder River structural basin. 




Figure 6.-Chemical-quality stations in the Green River, Bear River, and Great Divide basins. 
Explanation of abbreviations and codes used in table 3 .

Period of Record: The dates given are the calendar years in which records began or ended. Breaks of less than a year are not shown.

Cooperator: BLM, Bureau of Land Management

BRUC, Bureau of Reclamation, Upper Colorado Region

EPA, Environmental Protection Agency--Region 8

MRB, Missouri River basin project

USGS, Geological Survey--Federal Program

WDA, Wyoming Department of Agriculture

WDEQ, Wyoming Department of Environmental Quality

Sampling Frequency:

D, daily

$\mathrm{BW}$, biweekly

BWM, biweekly and (or) monthly

$M$, monthly

MW, monthly, except weekly during irrigation season

$\mathrm{MQ}$, monthly during summer, quarterly during winter

$Q$, quarterly

HL, high and low flow samples only

Analysis Schedule:

1, salinity (major constituents)

2, specific conductance

3, daily temperature (observed)

4, bacteria or chemical oxygen demand

5, field determinations of: $\mathrm{pH}$, specific conductance, dissolved oxygen, temperature, and (or) turbidity

6, total coliform, fecal coliform, and (or) fecal streptococcus

7 , nutrient

8, trace metals

9, pesticides

10, radiochemical

11, biological

12, miscellaneous

Field Office: $\mathrm{CH}$, Cheyenne

C, Casper

$R$, Riverton 
Table 3. Chemical-Quality Stations

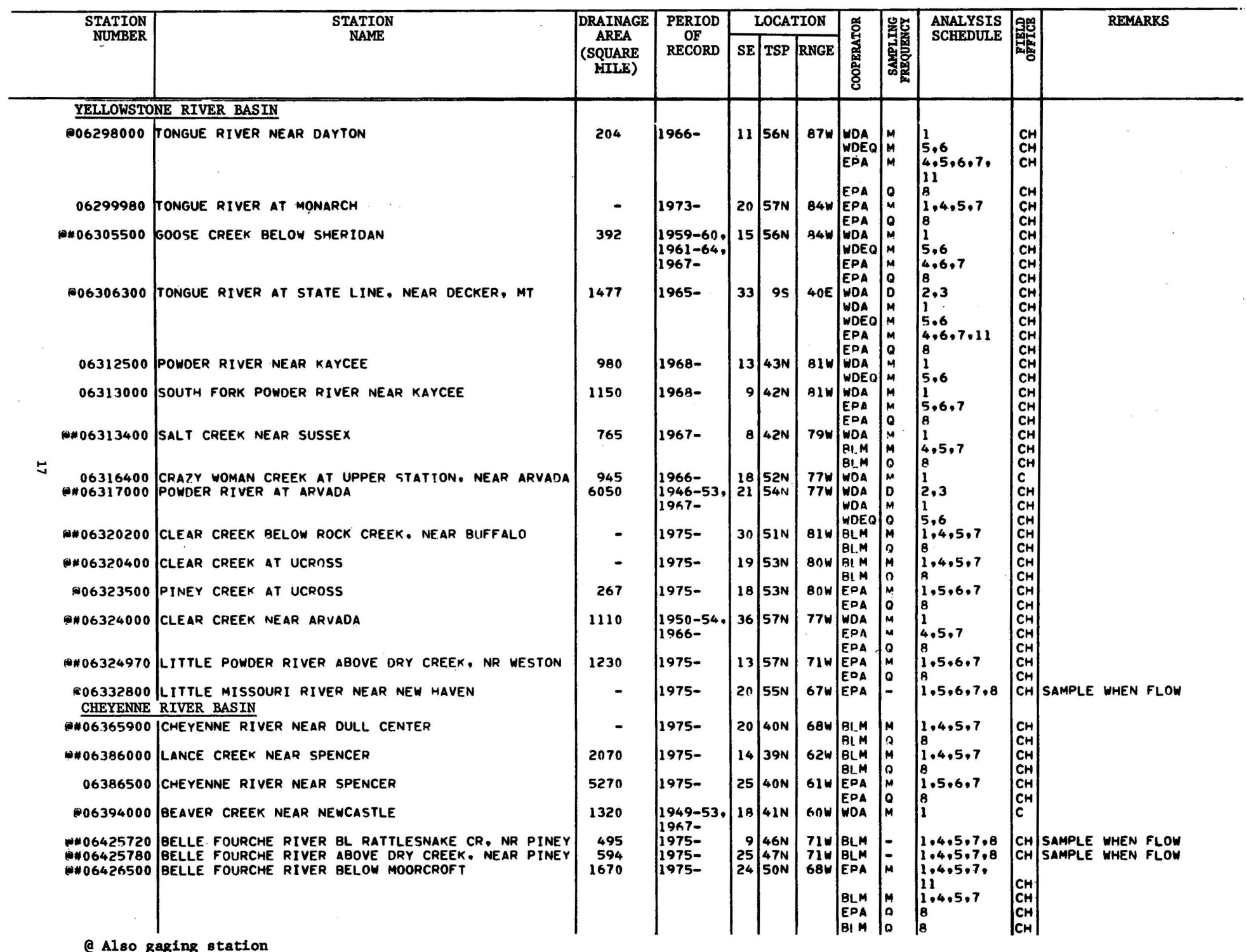

(a) Also gaging station
* Also sediment station 
Table 3. Chemical-Quality Stations (Continued)

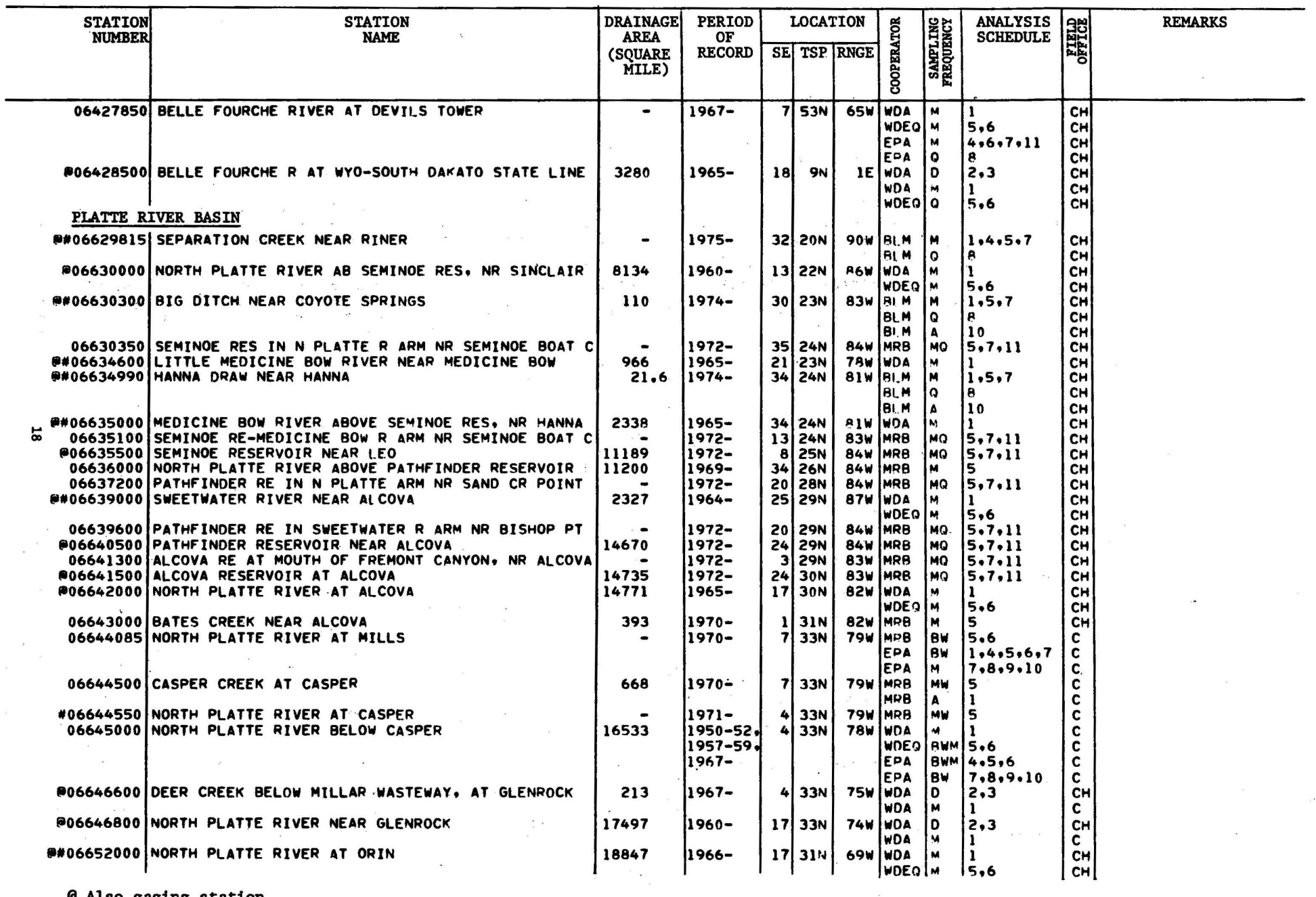

also gaging station 
Table 3. Chemical-Quality Stations (Continued)




Table 3. Chemical-Quality Stations (Continued)

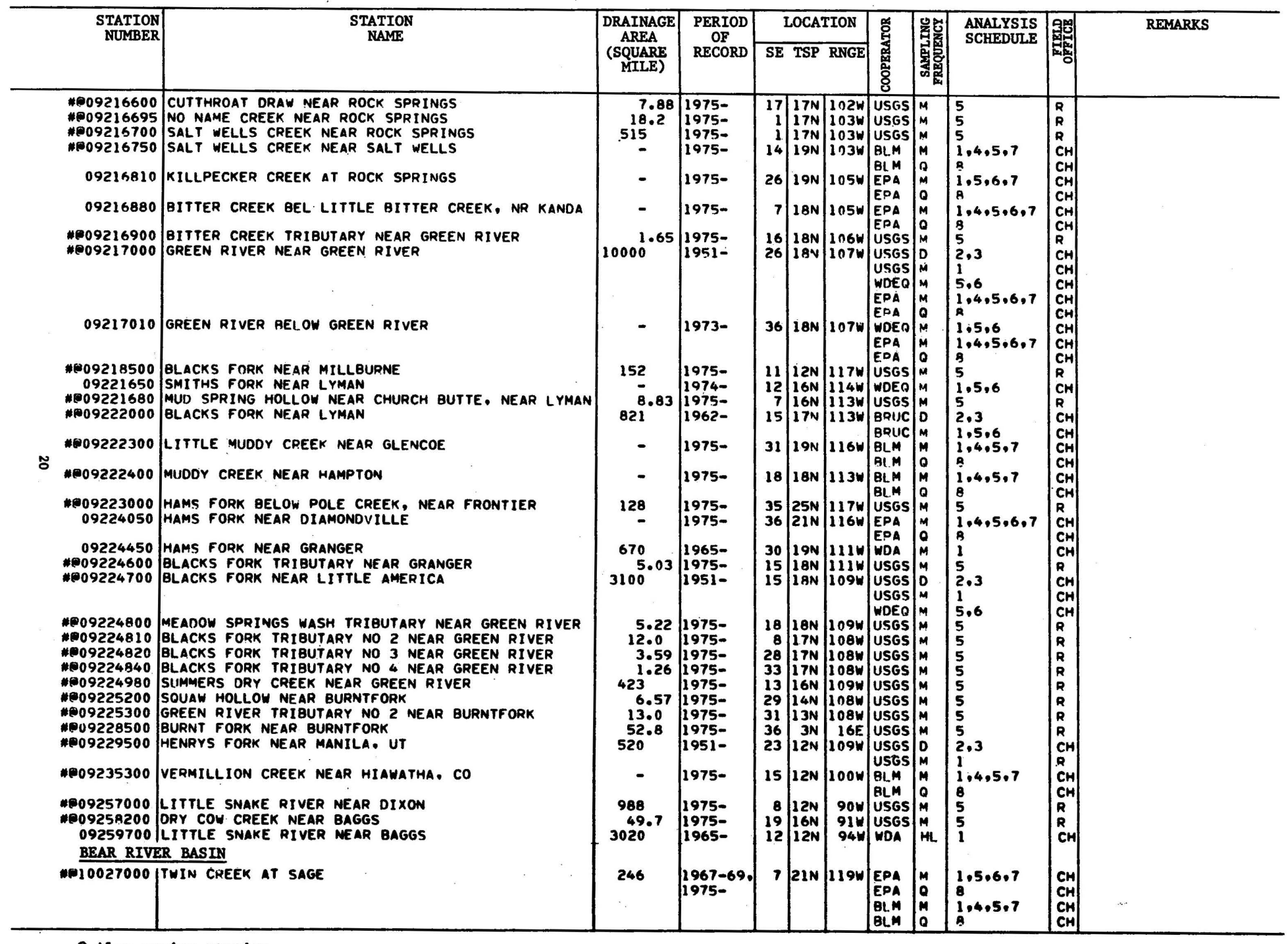

A Also gaging station
f Also sediment station 


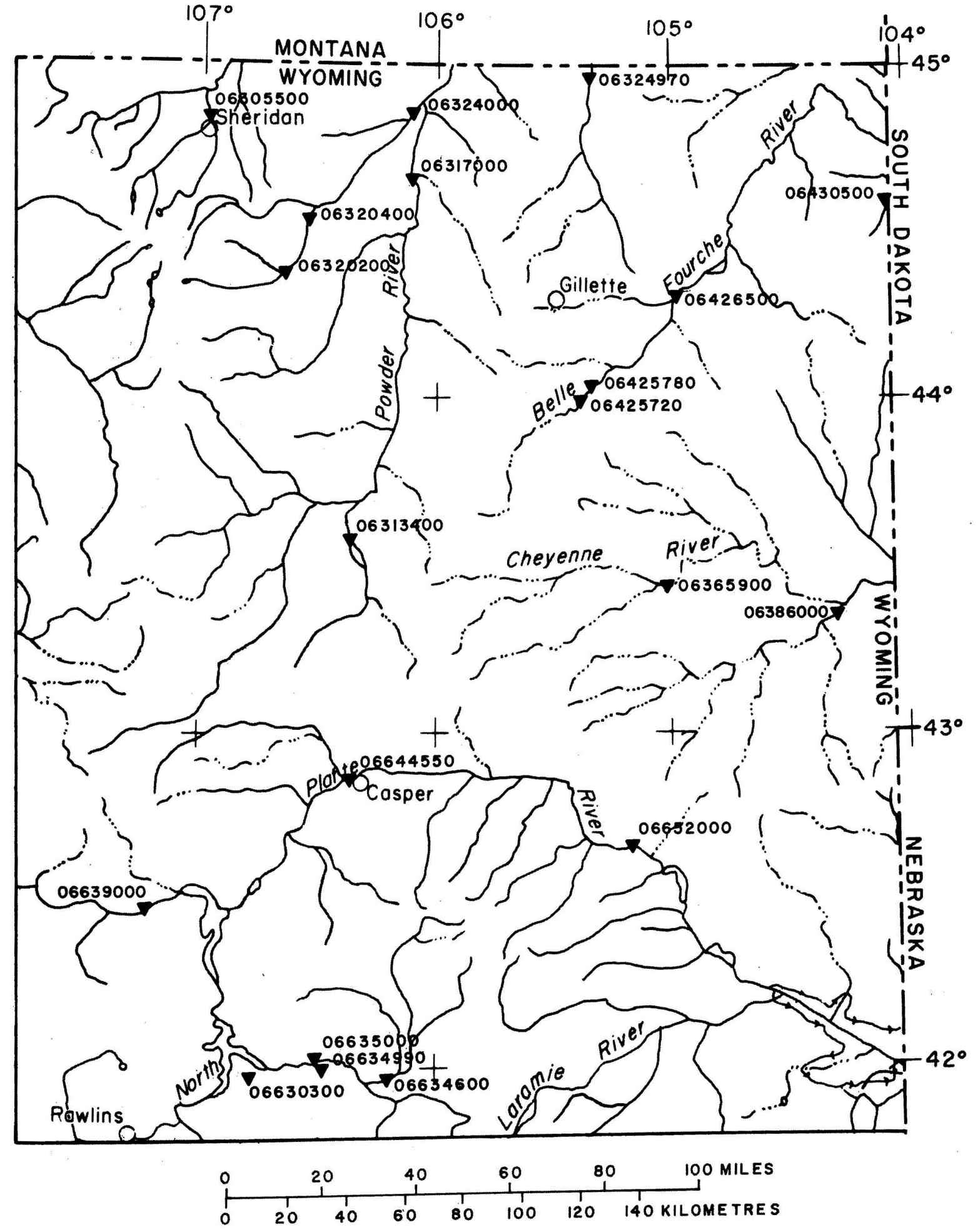

Figure 7.- Sediment stations in the Powder River structural basin. 


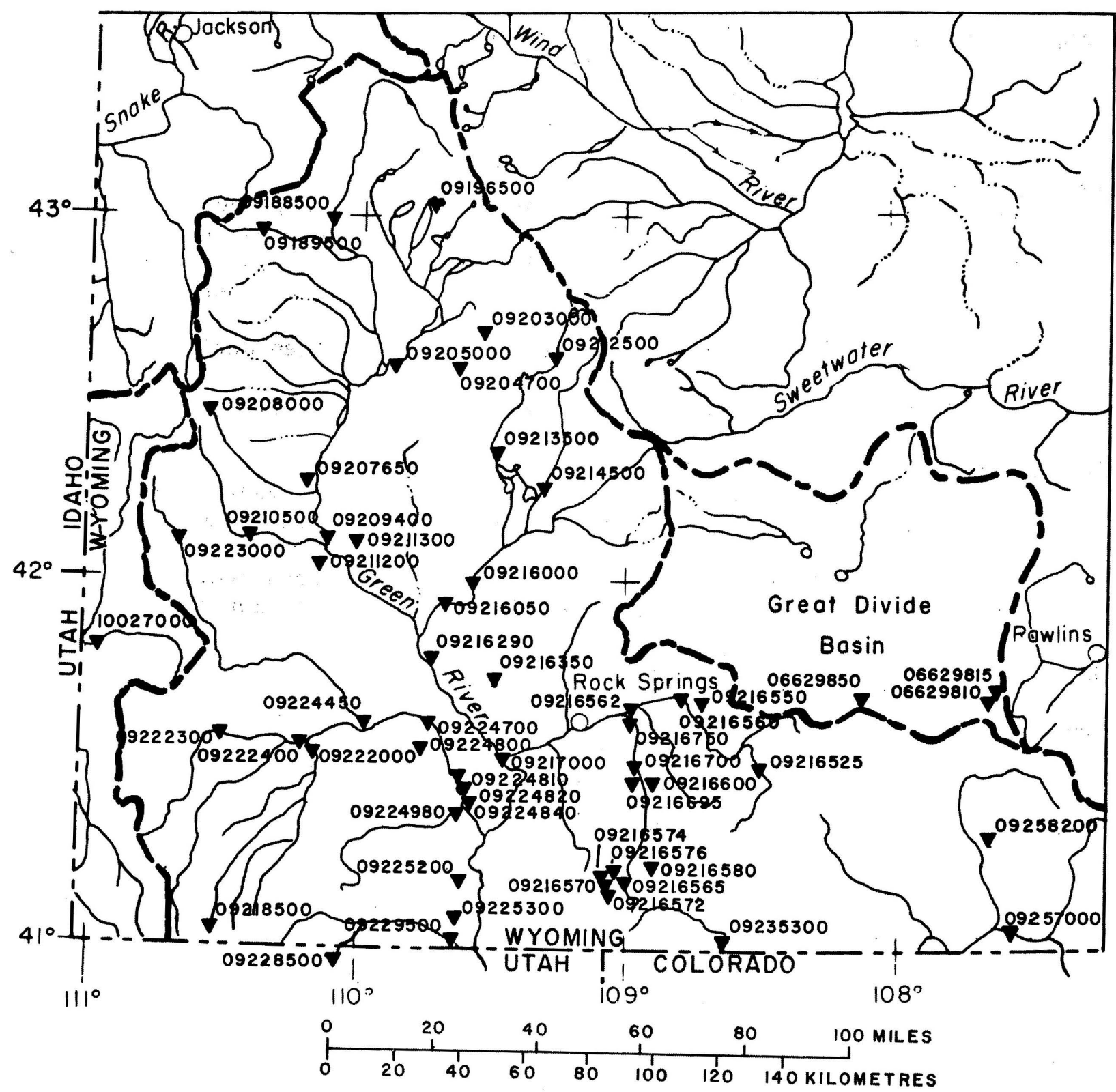

Figure 8.-Sediment stations in the Green

River, Bear River, and Great Divide basins. 
Explanation of abbreviations and codes used in table 4 .

Period of Record: The dates given are the calendar years in which records began or ended. Breaks of less than a year are not shown.

Sampling Equipment: $H$, hydrographers sample

0 , observer sample

$P$, pumping sampler

$S$, single-stage samplers

Suspended Sediment Sampling Frequency:

1, samples collected by observer once daily except during periods of rapidly changing flow when additional samples are collected.

3, sampled by hydrographer at least once a month during openwater period and at least twice during extended periods of ice cover.

7, pumping sampler serviced monthly or more of ten during periods of high runoff.

8, single-stage sampler serviced at least monthly.

Bed Material Sampling Frequency:

1, sample the surficial bed material by pebble count methods in cross section once a year at approximately the same time each year.

3, sample the surficial bed material in the cross section at least three times per year (high, medium, and low flow).

Laboratory: W, Worland

Cooperator: WSE, Wyoming State Engineer

BLM, Bureau of Land Management

USGS, Geological Survey--Federal Program

Field Office: W, Worland

C, Casper

$\mathrm{CH}$, Cheyenne

$\mathrm{R}$, Riverton 
Table 4. Sediment Stations

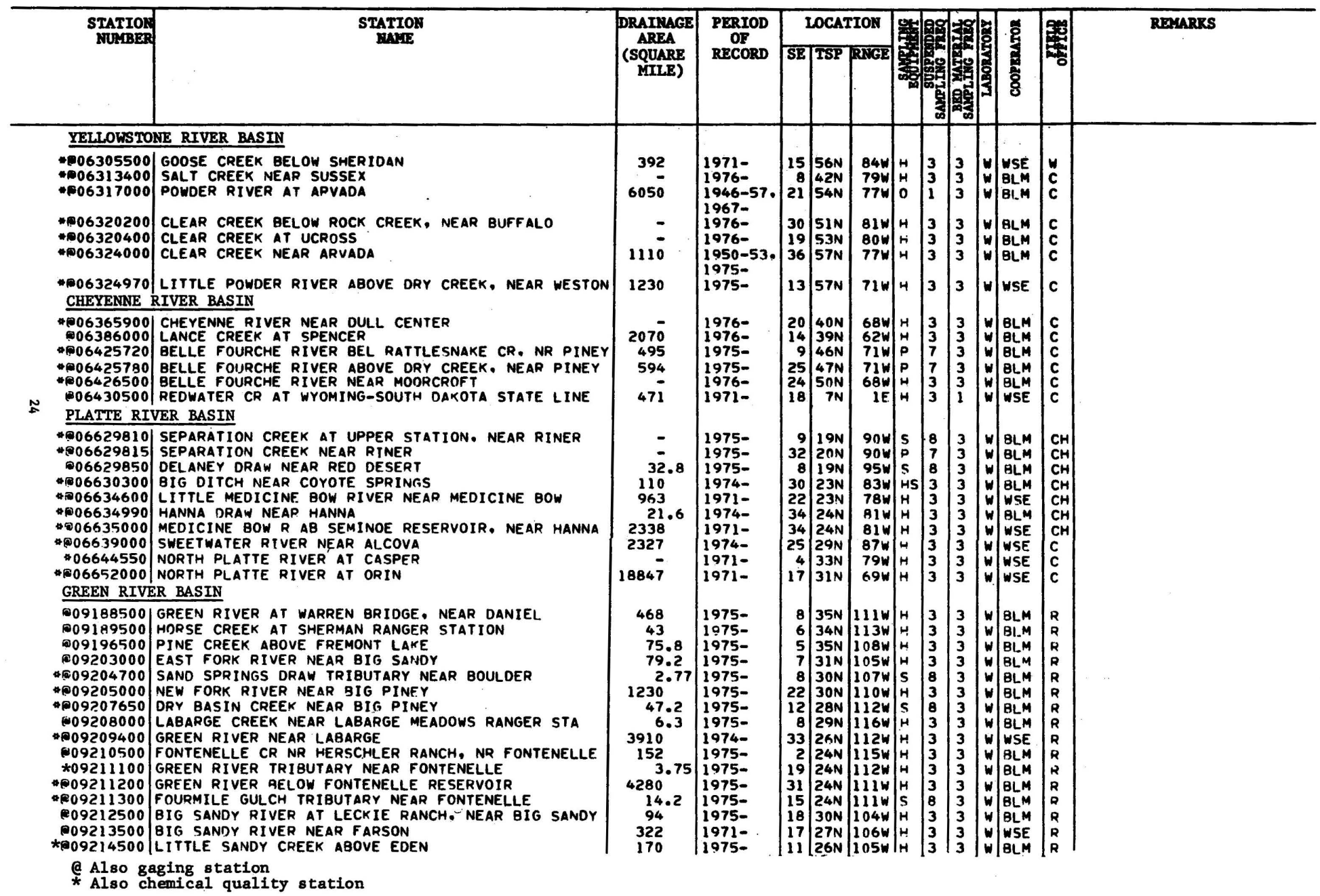


Table 4. Sediment Stations (Continued)

\begin{tabular}{|c|c|c|c|c|c|c|c|c|c|c|c|c|c|}
\hline & \multirow[t]{2}{*}{$\begin{array}{l}\text { STATION } \\
\text { NUMBER }\end{array}$} & \multirow[t]{2}{*}{$\begin{array}{c}\text { STATION } \\
\text { NAME }\end{array}$} & \multirow{2}{*}{$\begin{array}{c}\text { DRAINAGE } \\
\text { AREA } \\
\text { (SQUARE } \\
\text { MILE) }\end{array}$} & \multirow{2}{*}{$\begin{array}{l}\text { PERIOD } \\
\text { OF } \\
\text { RECORD }\end{array}$} & \multicolumn{3}{|c|}{ LOCATION } & \multirow{2}{*}{\multicolumn{3}{|c|}{ 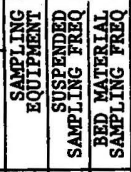 }} & \multirow{2}{*}{ 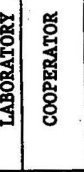 } & \multirow{2}{*}{ 率囼 } & \multirow[t]{2}{*}{ REMARKS } \\
\hline & & & & & \begin{tabular}{|l|}
$\mathrm{SE}$ \\
\end{tabular} & TSP & RNGE & & & & & & \\
\hline$\tilde{u}$ & 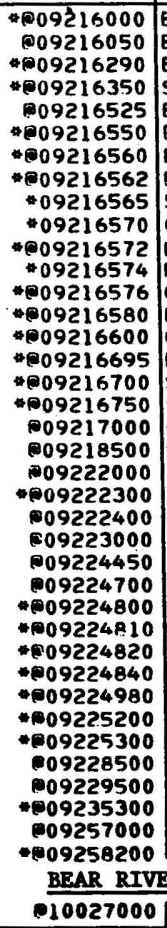 & 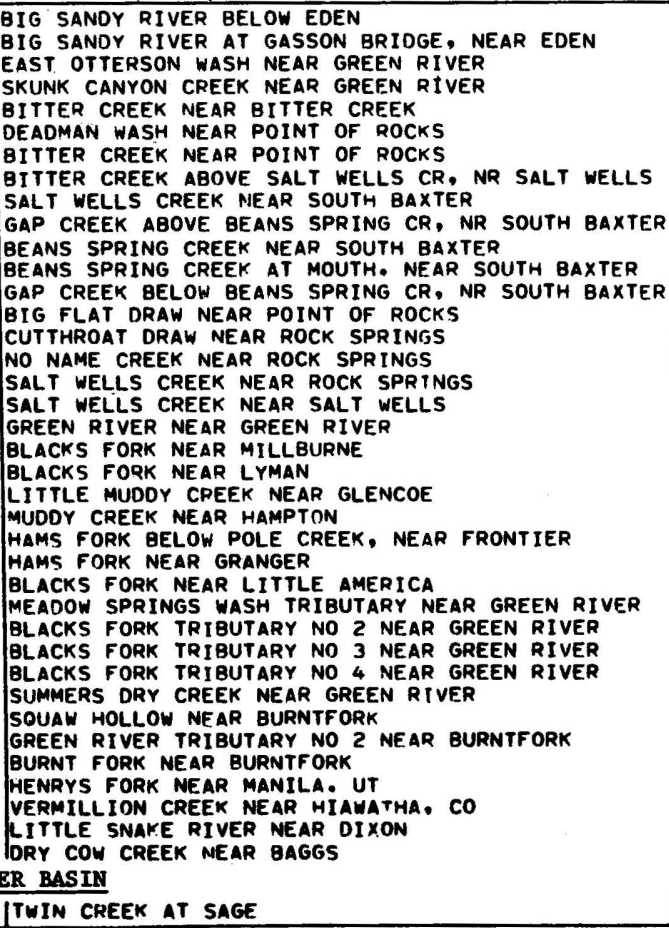 & \begin{tabular}{|c|}
1610 \\
1720 \\
16.6 \\
15.7 \\
152 \\
759 \\
- \\
- \\
- \\
5 \\
19.5 \\
7.88 \\
18.2 \\
515 \\
100 \\
1000 \\
152 \\
821 \\
$5-$ \\
128 \\
670 \\
3100 \\
5.22 \\
12.0 \\
3.59 \\
41.26 \\
623 \\
6.57 \\
13.0 \\
52.8 \\
520 \\
988 \\
49.7 \\
\end{tabular} & $\begin{array}{l}1971- \\
1975- \\
1075- \\
1975- \\
1976- \\
1975- \\
1975- \\
1976- \\
1975- \\
1975- \\
1975- \\
1975- \\
1975- \\
1975- \\
1975- \\
1975- \\
1975- \\
1976- \\
1951- \\
1975- \\
1971- \\
1976- \\
1976- \\
1975- \\
1971- \\
1967- \\
1975- \\
1975- \\
1975- \\
1975- \\
1975- \\
1975- \\
1975- \\
1975- \\
1975- \\
1976- \\
1971- \\
1975- \\
197 \\
1976-\end{array}$ & \begin{tabular}{|r|}
31 \\
29 \\
23 \\
8 \\
36 \\
25 \\
27 \\
2 \\
15 \\
18 \\
25 \\
18 \\
7 \\
4 \\
17 \\
1 \\
1 \\
14 \\
26 \\
11 \\
15 \\
31 \\
18 \\
35 \\
30 \\
15 \\
18 \\
8 \\
28 \\
33 \\
13 \\
29 \\
31 \\
36 \\
23 \\
15 \\
8 \\
19 \\
\end{tabular} & $\begin{array}{l}24 N \\
23 N \\
21 N \\
20 N \\
18 N \\
20 N \\
20 N \\
19 N \\
14 N \\
14 N \\
14 N \\
14 N \\
14 N \\
15 N \\
17 N \\
17 N \\
17 N \\
19 N \\
18 N \\
12 N \\
17 N \\
19 N \\
18 N \\
25 N \\
19 N \\
18 N \\
18 N \\
17 N \\
17 N \\
17 N \\
16 N \\
14 N \\
13 N \\
3 N N \\
12 N \\
12 N \\
12 N \\
16 N\end{array}$ & 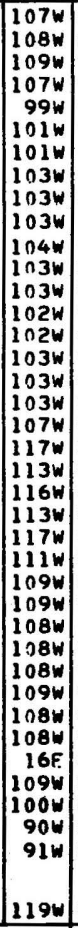 & 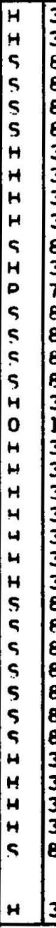 & \begin{tabular}{|l|l}
3 & 3 \\
3 & 3 \\
8 & 3 \\
8 & 3 \\
8 & 3 \\
8 & 3 \\
3 & 3 \\
3 & 3 \\
3 & 3 \\
3 & 3 \\
8 & 3 \\
3 & 3 \\
7 & 3 \\
8 & 3 \\
8 & 3 \\
8 & 3 \\
8 & 3 \\
3 & 3 \\
1 & 1 \\
3 & 3 \\
3 & 3 \\
3 & 3 \\
3 & 3 \\
3 & 3 \\
3 & 3 \\
3 & 1 \\
8 & 3 \\
8 & 3 \\
8 & 3 \\
8 & 3 \\
8 & 3 \\
8 & 3 \\
8 & 3 \\
8 & 3 \\
3 & 3 \\
3 & 3 \\
3 & 3 \\
3 & 3 \\
8 & 3 \\
& 3
\end{tabular} & 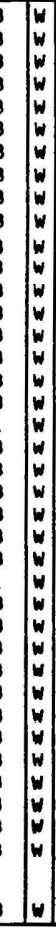 & 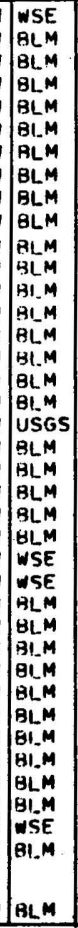 & $\begin{array}{l}R \\
R \\
R \\
R \\
R \\
R \\
R \\
R \\
R \\
R \\
R \\
R \\
R \\
R \\
R \\
R \\
R \\
R \\
R \\
R \\
R \\
R \\
R \\
R \\
R \\
R \\
R \\
R \\
R \\
R \\
R \\
R \\
R \\
R \\
R \\
R \\
R \\
R \\
R \\
R \\
R \\
R \\
R \\
R \\
R \\
R \\
R \\
R \\
R\end{array}$ & . \\
\hline
\end{tabular}

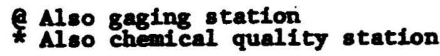






Figure 9.-Observation wells in the

Powder River structural basin.

Number indicates how many wells are repre-

sented by the symbol if more than one. 


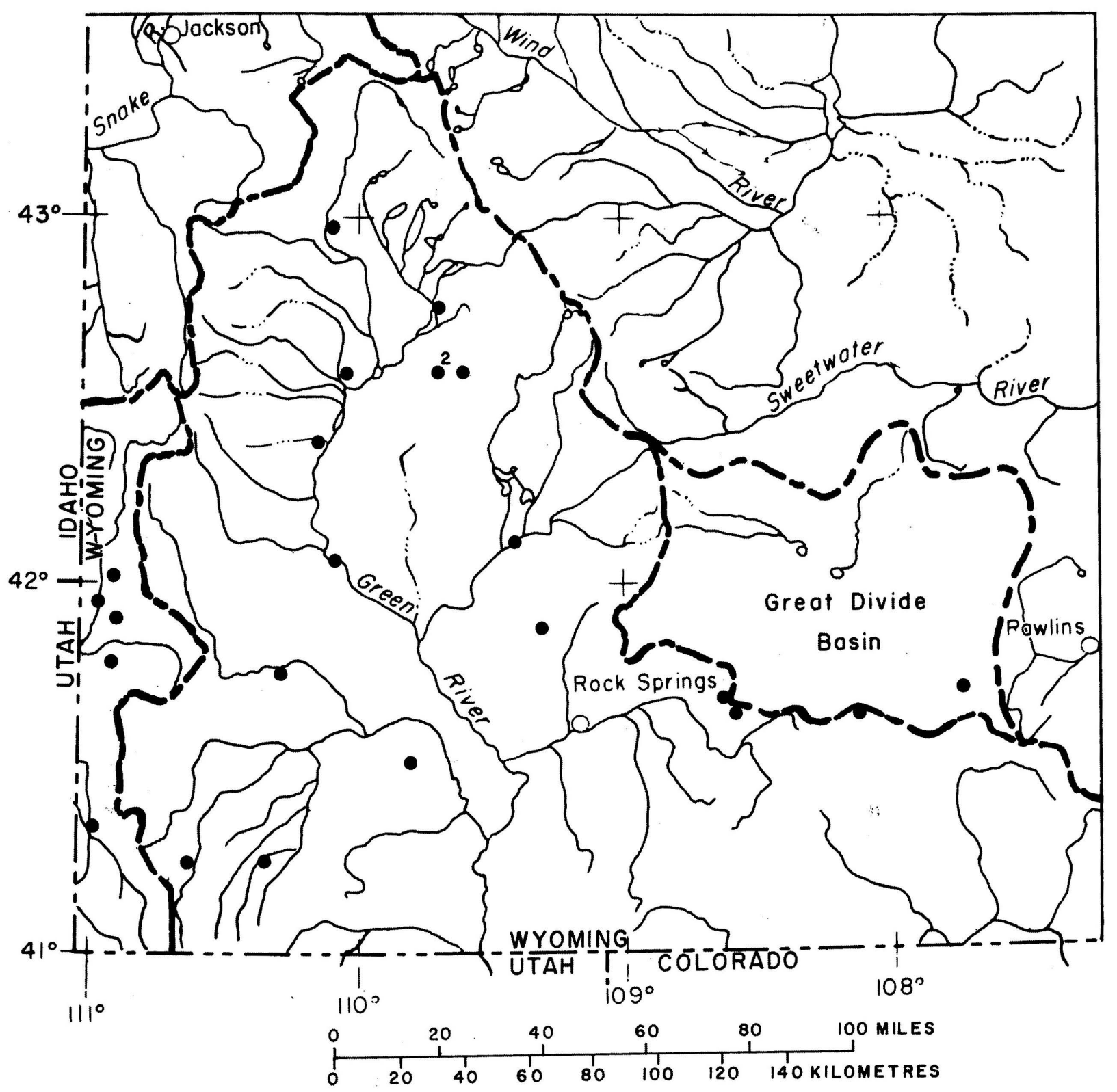

Figure 10.-Observation wells in the Green River, Bear River, and Great Divide basins. Number indicates how many wells are represented by the symbol if more than one. 
Explanation of abbreviations and codes used in table 5.

Lat-Long-Seq No: The first six digits are the latitude in degrees, minutes, and seconds. The next seven digits are the longitude in degrees, minutes, and seconds. The last two digits indicate the sequence number of when the well was inventoried in the event more than one well has the same latitude and longitude.

Geologic Unit:

111 ALVL Alluvial Deposits

111 TRRC Terrace Deposits

122 ARKR Arikaree Formation

123 WRVR White River Formation or Group

124 LNEY Laney Shale Member of Green River Formation

124 WSTC Wasatch Formation

125 FRUN Fort Union Formation

211 ALMD Almond Formation
211 FXHL Fox Hills Sandstone
211 LNCE Lance Formation
217 LKOT Lakota Formation
221 SNDC
230 SPRF
317 MNKT
331 MDSN
337 PHSP
374 FLTD Formation Spearfish Formation Minnekahta Limestone Madison Limestone Pahasapa Limestone Flathead Quartzite or Sandstone

Cooperator: WSE, Wyoming State Engineer

Field Office: W, Worland

C, Casper

$\mathrm{CH}$, Cheyenne

$\mathrm{R}$, Riverton

Frequency of Observation:

C, continuous (graphic or digital recorder)

$M$, monthly (12 visits per year)

$B M$, bimonthly (6 visits per year)

$Q$, quarterly ( 4 visits per year)

$\mathrm{SA}$, semiannual (2 visits per year)

$A$, annual (1 visit per year)

Period of Record: The dates given are the calendar years in which records began or ended. A record consists of one or more measurements during a calendar year. 
Table 5. Observation Wells

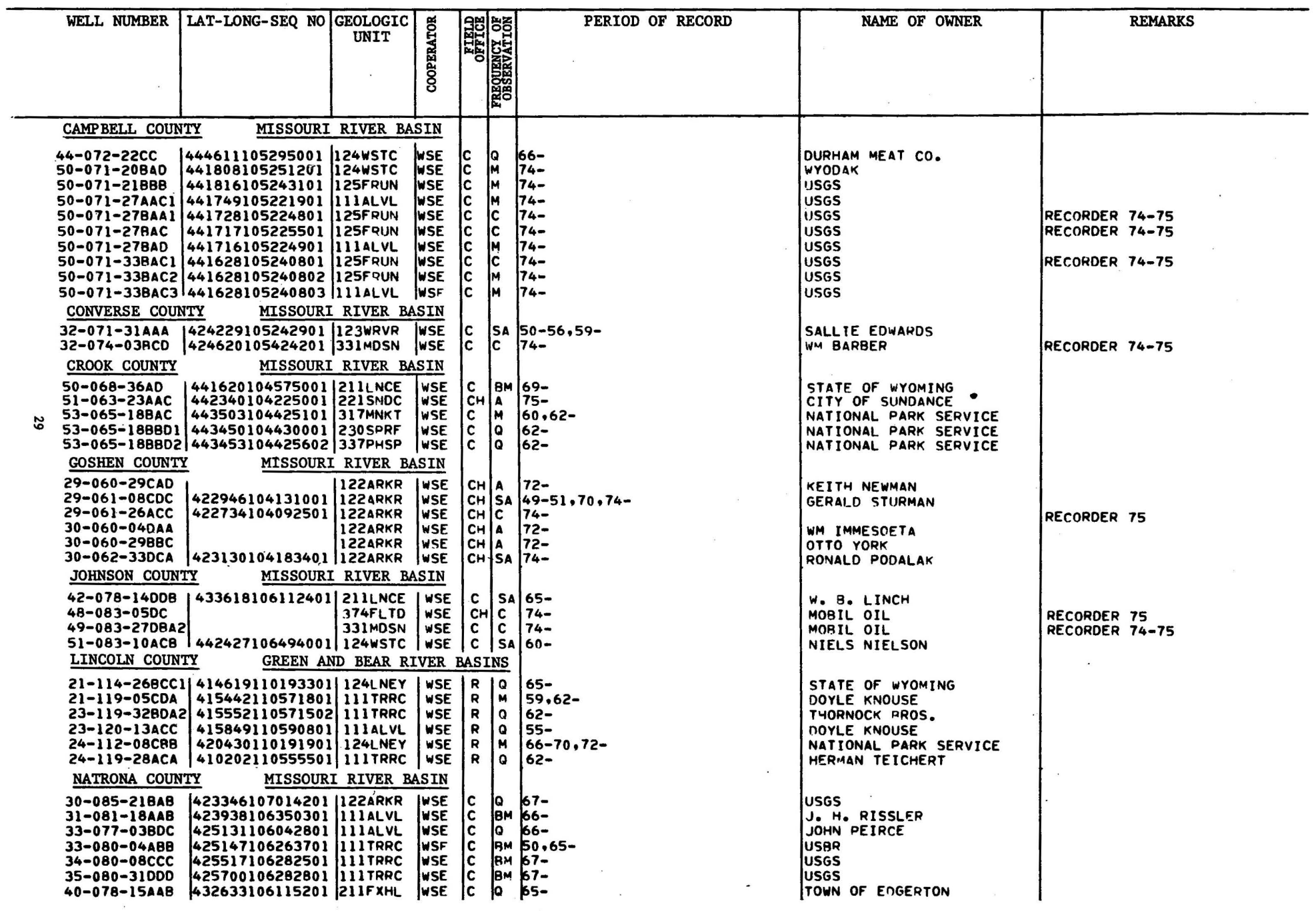


Tab1e 5. Observation Wells (Continued)

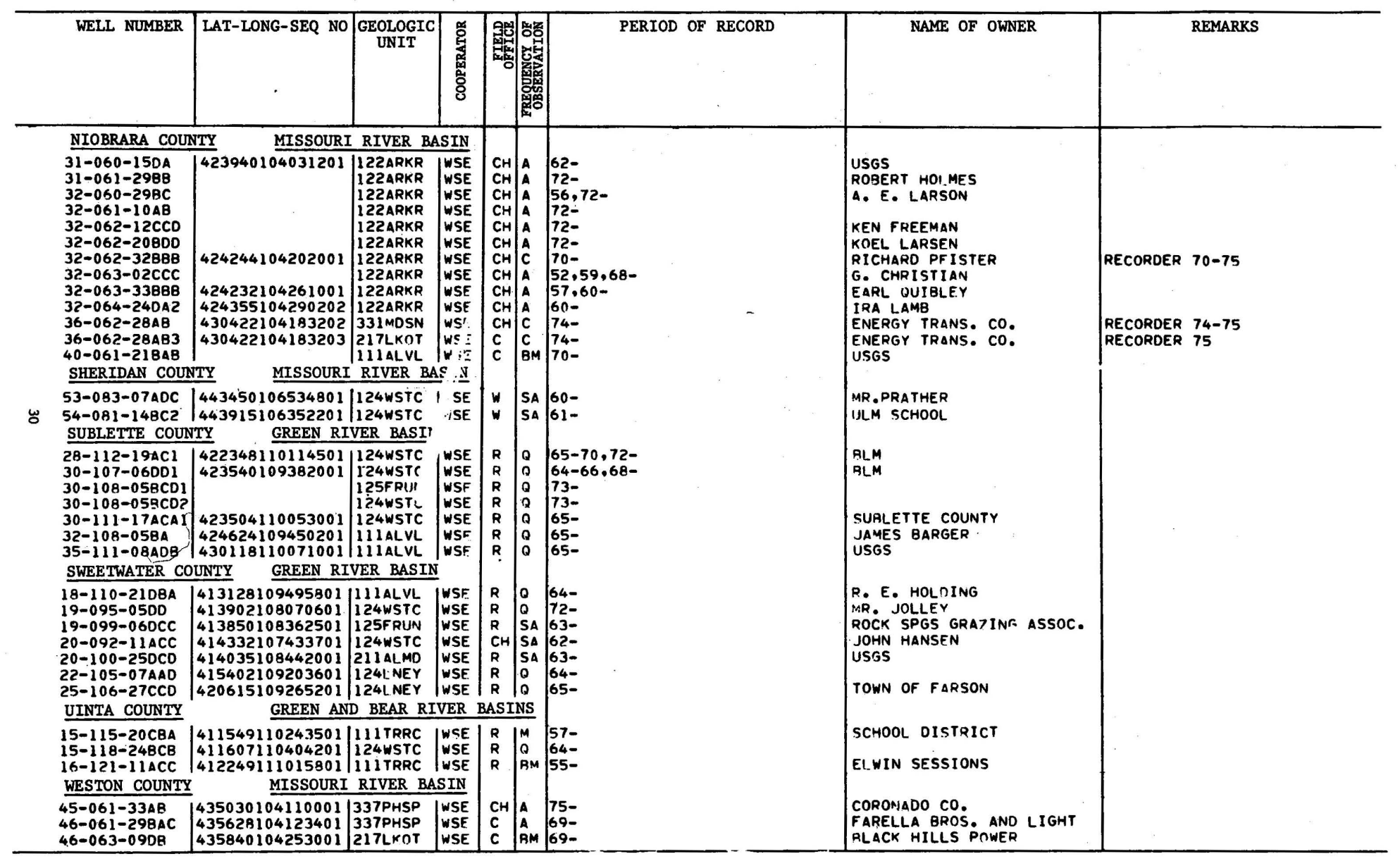




\section{Water Resources of Weston County, Wyoming}

$$
\text { (Project, WY 74-026C) }
$$

Funds: Wyoming State Engineer and U.S. Geological Survey

The objectives are to determine: (1) The distribution (areally and vertically) and thickness of each of the principal aquifers or aquifer systems; (2) the movement of water in each of the principal aquifers or aquifer systems; (3) the hydraulic characteristics for each principal aquifer or aquifer system; (4) the water-bearing properties of subordinate aquifers; (5) the volume of ground water in storage; (6) the quality of water in each aquifer; (7) the quantity of runoff from small watersheds; (8) the quality of runoff at gaged sites; (9) the effect of ground-water withdrawal on water levels; and (10) to evaluate the potential for artificial recharge.

The approaches required to meet these objectives will be to make a well inventory and periodic water-level measurements; collect and analyze water samples; make pumping tests to determine aquifer characteristics; collect and analyze rock samples for water-bearing characteristics; auger cross sections of major drainages; inventory ground-water use; tabulate existing data; compile geologic map and cross sections; prepare structurecontour and isopach maps of principal aquifers; calculate volume of ground water in storage (by aquifer) and show on maps; construct potentiometric and depth-to-water maps for principal aquifers; analyze well-field histories; evaluate potential for artificial recharge; and describe runoff characteristics for small basins, using channel-geometry techniques.

Measurement of Water Losses to the Madison Limestone and Associated Rocks from Streams in Northeastern Wyomming

(Project WY 75-028C)

Funds: Wyoming State Engineer (sponsored by 01d West Regional Commission)

This is primarily a basic-data collection project, the objectives of which are: (1) Determination of the magnitude and areal distribution of losses to the Madison by streams which cross the outcrop area; (2) determination of precipitation, runoff, infiltration relationships in outcrop areas; and (3) establishment of baseline streamflow conditions prior to possible increased development of Madison Limestone water. 
To achieve the objectives it was necessary to: (1) Make a field survey of the geologic and hydrologic conditions of all perennial streams crossing Madison outcrops; (2) operate 32 new and 5 existing gaging stations at sites above and below the outcrop; (3) make three sets of streamflow measurements each year on 30 additional streams at sites above and below the outcrop; (4) collect precipitation data (storage gages) near some streamflow sites; (5) estimate mean annual discharge at all sites by channel geometry techniques; (6) analyze the precipitation and streamflow data to determine short-term losses from streams to the Madison Limestone, and to design a post-project monitoring program. The 32 gaging stations in Item 2 above are included in the list of streamflow stations (table 1 ) and are identified by the cooperator code "028".

Water and its Relation to Economic Development in the Green River and Great Divide Basins in Wyoming

(Project WY 75-030FI)

Funds: U.S. Geological Survey, with basic-data support funds from U.S. Bureau of Land Management

The study is designed to gather information and make available to interested industrial, agricultural, and governmental people, interpretive reports that describe: (1) The distribution and quality of surface water In space and time; (2) relationships between surface water and ground water; (3) the distribution, quantity, and quality of ground water; and (4) hydrology-related aspects of the environment. Efforts of the study are directed toward: (1) Describing the water resources and hydrologic relationships that presently exist; (2) developing predictive methods that may be used to describe future conditions, including reactions to increased water development; and (3) establishing monitoring programs for detecting possible changes in water parameters.

A planning report has been prepared during the first year of the project, outlining the specific techniques to be used in subsequent phases. Regarding water quality, particular attention is being given to trace metals, biological parameters, and trend analysis. Channel-geometry techniques, ERTS imagery, and detailed statistical analyses are being applied to surface-water studies. Aquifer tests and bore hole and surface geophysical surveys are being used in ground-water studies. Aquifer tests and bore hole and surface geophysical surveys are being used in groundwater studies. Digital models are being developed for chemical-quality and surface-water systems. 
Impacts of Economic Development and Water Use on Water Resources in the Hanna Basin in Wyoming

(Project WY 75-031FI)

Funds: U.S. Geological Survey and U.S. Bureau of Land Management

The objectives of the project are to describe the present characteristics of the hydrologic environment, to monitor changes in it, and to evaluate the effects of those changes. On the surface, peak and annual flows, channel geometry, sedimentation rates, erosion rates, uses, and quality of water will be investigated. In the subsurface, aquifer characteristics, ground-water uses, and pumping amounts will be estimated.

The approach will be to: (1) Describe streamflow conditions--evaluate past records, establish two new gaging sites for flow measurements, sediment sampling, and chemical quality (use channel geometry methods where necessary); and (2) define aquifer characteristics--perform aquifer tests, draw potentiometric maps, analyze water quality, and identify recharge and discharge areas. The two new gaging stations, Hanna Draw near Hanna and Big Ditch near Coyote Springs, are included in the lists of streamflow, chemical-quality, and sediment stations (tables 1, 3, and 4).

Water Resources of the Powder River Structural Basin in Wyoming in Relation to Energy Development

(Project WY 75-032FøI)

Funds: U.S. Geological Survey, with basic-data support funds from U.S. Bureau of Land Management and U.S. Environmental Protection Agency

The study is designed to gather information and make available to industrial, governmental, and other interested people, interpretive reports that describe the water supply in the area and the possible impact of planned development on the water resources.

A planning report was prepared during the first year of the project, outlining the approach to be used in the study. Techniques included are those for determination of aquifer properties, streamflow analysis, channel geometry, isotope study, biological assay, water budgets, modeling, and geophysics. 
Hydrology of Paleozoic Rocks in the Powder River Basin and Adjacent Areas, Northeastern Wyoming

(Project WY 75-033F)

Funds: U.S. Geological Survey

The project is designed to derive a conceptual model of the aquifer system to better predict the quantity and quality of water available from the Paleozoic rocks and to predict some of the effects of its development. Principal objectives will be to determine: (1) The distribution, thickness, and physical properties of the aquifer system; (2) processes that developed the present distribution of aquifer parameters in order to extend point data to other parts of the aquifer system; (3) the potentiometric surface and chemical quality of the water in the aquifer system; and (4) the effects of increased development of water from the aquifer system.

Additional observation wells were established in the Madison Limestone and in both the overlying and in the underlying rocks for historical record of water levels. Water-level recorders were installed on some observation wells; other wells were measured periodically. Pressure transducers coupled to digital recorders were installed in some wells where water levels are several hundreds of feet below land surface. Collection and analysis of water samples from Paleozoic rocks are continuing.

A stream-gaging station was established inside Tongue River cave, and geologic mapping of the cave is in progress to determine stratigraphy of the cave. An inventory was started of solution cavities to determine the relation of modern solution features to relict caves and karst features. Also, an inventory of springs and sinks in outcrop areas was started.

Vertical seismic profiles were made to define the basic acoustic properties of the Madison relating to lithology and porosity. Minnelusa and Madison oil-test data were assembled, and maps showing structure, potentiometric surface, and thickness were prepared. Geophysical logs were purchased and analyzed for porosity, lithology, density, sonic travel time, and water resistivity for the upper Minnelusa. Synthetic seismograms were made from sonic logs to show significant acoustic differences between varlous porosities. Theoretrical gravity values were calculated for various limestone porosities.

Program and data decks for digital model have been received from L. Konikow and several of Konikow's runs were duplicated to insure consistant operation of the model. Minor alterations were inserted into the program regarding input and output procedures. 
Algal Growth Potential of Principal

North Platte River Reservoirs in Wyoming

(Project WY 76-035F)

Fụnds: U.S. Geological Survey (Missouri River basin program)

Eutrophic conditions may be developing in one or more of the four major reservoirs on the North Platte River (Seminoe, Pathfinder, Alcova, and Glendo). Oxygen depletion could have an adverse effect on recreational use of the reservoirs and of fish habitat. Development of mineral resources, particularly coal mining, is taking place at locations adjacent to one of the reservoirs. There is no information about the present state of algal growth with which to evaluate the seriousness of the problem, to evaluate changes caused by mining activities, or to predict future trends.

The objectives of the study are to: (1) Determine the extent of algal growth in the four major reservoirs; (2) evaluate trends in algal growth potential, including effects of effluent from coal mining activities adjacent to the reservoirs; and (3) determine the feasibility of developing a model for predicting algal growth.

The first 3 years will be devoted exclusively to data collection, with analysis of data and preparation of a report scheduled for the fourth year. Vertical-profile water samples will be collected monthly (MayOctober) from a boat at sites above the dams and in the principal arms of each reservoir. Sampling will also be done twice each winter. Field parameters will include dissolved oxygen and temperature. Laboratory parameters will include $\mathrm{NH}_{4}, \mathrm{NO}_{2}+\mathrm{NO}_{3}, \mathrm{P}$, residue, and AGP. A set of phytoplankton samples will be collected each year in early spring and in late summer for identification of genera. Graphical and statistical techniques, such as regression, will be used.

Availability of Ground Water from the Cretaceous and Tertiary Aquifers of the Fort Union Coal Region

(Project ND 75-071F)

Funds: U.S. Geological Survey

This investigation is a compilation of existing data from South Dakota, North Dakota, Montana, and Wyoming of the Tertlary rocks and aquifers overlying the Pierre Shale. The objectives of the investigation are: (1) To determine the location, extent, and nature of the aquifers and confining beds; (2) to evaluate the occurrence and movement of ground water, including the sources of recharge and discharge; and (3) to determine the chemcial quality of the ground water. This project is being done by the North Dakota District, Water Resources Division, U.S. Geological Survey, headquartered in Bismarck, North Dakota. 


\section{Geochemical Survey of Waters of the Western Coal Regions}

(Project CR 74-095F)

\section{Funds: U.S. Geological Survey}

The purpose of this project is to efficiently provide a broad-scale description of the "natural" or pre-development geochemistry of waters in the western coal and oil shale areas, with particular emphasis on trace elements. The project is being carried out in association with concurrent studies on soils, rocks, and plants by the Geologic Division, Branch of Regional Geochemistry.

\section{Channe1 Changes in the Powder River}

(Project CR 75-102F)

Funds: U.S. Geological Survey

After it leaves the Bighorn Mountains, the Powder River flows in an alluvial channel. Like other alluvial channels, that of the Powder River is constantly shifting by erosion, by lateral accretion, and by occasional cutting off of bends. As of now, the channel of the Powder River and the rates at which it shifts have been affected very little by human activities.

Rates of channel migration will be measured in the 110-mile (170kilometre) reach of the Powder River between Arvada, Wyoming, and Broadus, Montana. This reach was selected because sediment loads are sampled daily at Arvada and at Moorhead (about halfway down the reach), and we hope that daily sampling will soon begin at Broadus. Another reason for selecting this reach is that it contains the site of a proposed reservoir to store water for energy development. If the reservoir is built, we will be able to assess its effects on the river channel.

\section{Red Rim EMRIA Study Site Near Rawlins, Wyoming}

$$
\text { (Project CR 75-104FI) }
$$

Funds: U.S. Geological Survey and U.S. Bureau of Land Management

The Public Lands Hydrology Program is conducting reconnaissance studies on the 2,640-acre (1,070-square hectometre) Red Rim EMRIA study site near Rawlins, Wyoming, to provide data for evaluating rehabilitation potential of that area with respect to prospective surface mining for coal.

A map showing annual source-area sediment yields is being prepared. The relations of sediment yield to percent bare soil and average watershed slope will be described for use in surrounding areas having similar climate and watershed characteristics. Estimates will be made of the amount of sediment contributed from the study-site area to Separation Creek. 
A map of the vegetation-soil units on the site was prepared from aerial photographs and on-site measurements. Vegetation, mulch and rock cover, and percent bare soil were measured in each unit, Internal water stress in the woody plants present was also measured. Small plots of vegetation were clipped to determine the yield of the various species.

Soll samples were obtained to the depth of active rooting in each vegetation-soil unit. The depth of rooting was used along with moistureretention forces and bulk density of the soll to estimate the annual evapotranspiration. The welght of roots, the electrical conductivity, $\mathrm{pH}$, and relative erodibility were measured in the laboratory for each soil sample. These data will be useful in selecting sultable vegetation species for rehabilitation of the area if $i t$ is mined and in determination of whether or not furrowing, pitting, or terracing will be needed to enhance vegetation establishment and to minimize runoff and erosion.

The rainfall simulator will be used during spring 1976 on five microwatersheds, each approximately 3,600 square feet ( 330 square metres), to determine runoff, sediment yield, and chemical yield under various cover and slope conditions.

Potter Mountain EMRIA Study Site Near Rock Springs, Wyoming

$$
\text { (Project CR 75-104FI) }
$$

Funds: U.S. Geological Survey and U.S. Bureau of Land Management

The Public Lands Hydrology Program is conducting reconnaissance studies on the 3,080-acre (1,250-square hectometre) Potter Mountain EMRIA study site near Rock Springs, Wyoming, to provide data for evaluating the rehabilitation potential of that area after prospective surface mining for coal.

A map showing annual source-area sediment yields is being prepared and the relations of sediment yield to percent bare soil and average watershed slope will be described for use in surrounding areas having similar climate and watershed characteristics. Estimates will be made of the amount of sediment contributed from the study site area to Gap Creek.

A map of the vegetation-soll units on the site was prepared from aerial photographs and on-site measurements. Vegetation, mulch and rock cover, and percent bare soll were measured in each unit. Internal water stress in the woody plants present were also measured. Small plots of vegetation were clipped to determine the yield of the various species.

Soll samples were obtained to the depth of active rooting in each vegetation-soil unit. The depth of rooting was used along with molstureretention forces and bulk density of the soil to estimate the annual evapotranspiration. The weight of roots, the electrical conductivity, $\mathrm{pH}$, and relative erodibility were measured in the laboratory for each soll sample. These data will be useful in selecting suitable vegetation species for rehabilitation of the area if it is mined and in determination of whether or not furrowing, pitting, or terracing will be needed to enhance vegetation establishment and to minimize runoff and erosion. 
The rainfall simulator will be used during spring 1976 on five microwatersheds, each approximately 3,600 square feet ( 330 square miles), to determine runoff, sediment yield, and chemical yield under various cover and slope conditions.

\section{Sediment Yield Estimates, Campbell County, Wyoming}

(Project CR 75-104FI)

Funds: U.S. Geological Survey and U.S. Bureau of Land Management

The disturbance of land that will accompany the surface mining of coal in Campbell County, Wyoming, will undoubtedly change the erosion and sediment yield patterns locally in the vicinity of mines. There are few suspended-sediment stations in this area and therefore little baseline information from which to assess possible changes. A draft of a map. of estimated sediment yields will be prepared in fiscal 1976 for the middle and southern two-thirds of Campbell County. The map will be based on the sediment surveys of 17 small reservoirs and characteristics of the associated watersheds in Campbell County, in addition to data from an earlier sediment yleld study in the upper Cheyenne River basin of Wyoming.

Sorption of Residual Organic Substances in Retort Waters by Spent Oil Shale Residues

(Project CR 75-181F)

Funds: U.S. Geological Survey

The purpose of the project is to determine the adsorptive capacities of spent oil shale and of soils and sediments associated with oil shales of the Green River Formation, for the organic solutes found in waste waters resulting from oil shale retorting. These adsorptive capacities will be used in predicting the rate at which organic solutes from retort waste waters will leach into ground water and run off into surface waters.

A preliminary objective was to develop analytical methodology such that baseline data of organic solutes in surface and ground water in regions of oil shale development can be collected. This methodology, called DOC Fractionation Analysis, was recently described in Technical Memorandum No. 76.05. Baseline data collected from applying DOC Fractionation Analysis to water samples collected in the Piceance Creek basin, Colorado; White River basin, Utah; and Sweetwater County area, Wyoming; will be used for the detection and monitoring of possible organic residual inputs from retort waste waters. 
The present (Dec. 1975) project activity is to characterize organic solutes in waste waters from oil shale retorts. Waste water samples have been furnished from a surface retort by the Laramie Energy Research Center (ERDA), and the organic solutes are presently being analyzed. In February 1976, waste water samples from an in-situ oil shale retorting experiment near Rock Springs, Wyoming, will also be provided by the Laramie Energy Research Center. The organic solutes are being isolated in large amounts (gram quantities) from the waste waters and are being analyzed with respect to their organic elemental composition, their compound class composition, their physical chemical properties, and the major specific compounds.

The final phase of the project will focus upon the adsorptive interactions of the organic solutes in the waste waters with the spent oil shale, soil, and sediment adsorbents. The surface chemistry of spent o1l shale, soll, and sediment adsorbents will be determined. The adsorption of organic solutes in waste waters upon the adsorbents will be studied by determining adsorptive capacities, running adsorption isotherms, and studying 'adsorption kinetics. 


\section{SELECTED REFERENCES}

Babcock, H. M., and Morr1s, D. A., 1953, Ground water in the vicinity of Edgerton, Wyoming: U.S. Geol. Survey open-file rept., 9 p., $1 \mathrm{fig}$.

Ballance, W. C., and Freudenthal, P. B., 1975, Ground-water levels in Wyoming, 1974: U.S. Geol. Survey open-f1le rept., 186 p.

Bolke, E. L., and Waddell, K. M., 1975, Chemical quality and temperature of water in Flaming Gorge Reservoir, Wyoming and Utah: U.S. Geol. Survey Water-Supply Paper 2039-A, 26 p., 1 pl.

Boner, F. C., Lowry, M. E., Lines, G. C., and Powe11, J. E., 1975, Geohydrologic reconnaissance and measurement of perennial streams crossing outcrops of the Madison Limestone, northeastern Wyoming, 1974: U.S. Geol. Survey open-f1le rept. 75-614, 64 p.

Crist, M. A., 1974, Selenium in waters in and adjacent to the Kendrick Project, Natrona County, Wyoming: U.S. Geol. Survey Water-Supply Paper 2023, 39 p., 3 pl.

1975, Hydrologic analysis of the valley-fill aquifer, North PLat,te River valley, Goshen County, Wyoming: U.S. Geol. Survey WaterResources Inv. 3-75, 60 p., 4 pl.

Crist, M. A., and Lowry, M. E., 1972, Ground-water resources of Natrona County, Wyoming: U.S. Geol. Survey Water-Supply Paper 1897, 92 p.

Culler, R. C., Hadley, R. F., and Schumm, S. A., 1961, Hydrology of the upper Cheyenne River basin--Part A. Hydrology of stock-water reservoirs in upper Cheyenne River basin, by R. C. Culler; Part B. Sediment sources and drainage-basin characteristics in upper Cheyenne River basin, by R. F. Hadley and S. A. Schumm: U.S. Geo1. Survey Water-Supply Paper 1531, 198 p.

Dav1s, G. H., and Wood, L. A., 1974, Water demands for expanding energy development: U.S. Geol. Survey Circ. 703, 14 p.

Frickel, D. G., and Shown, L. M., 1974, Annual streamflow in northeastern Wyoming and southeastern Montana: U.S. Geol. Survey Misc. Inv. Map I-847-B, 1 sheet.

Hodson, W. G., 1971a, Logs of wells in Campbell County: Wyoming State Engineer, Wyoming Water Plan. Program rept. no. 8, 210 p.

1971b, Chemical analyses of ground water in the Powder River basin and adjacent areas, northeastern Wyoming: Wyoming Dept. Econ. Plan. and Devel. rept., 20 p. 


\section{SELECTED REFERENCES--continued}

Hodson, W. G., 1974, Records of water wells, springs, o11- and gas-test holes, and chemical analyses of water for the Madison Limestone and equivalent rocks in the Powder River basin and adjacent areas, northeastern Wyoming: Wyoming State Engineer rept., 27 p.

Hodson, W. G., Pear1, R. H., and Druse, S. A., 1974, Water resources of the Powder River basin and adjacent areas, northeastern Wyoming: U.S. Geo1. Survey Hydrol. Inv. Atlas HA-465, 4 sheets.

Hudson, H. H., 1975, Water for Wyoming's coal: Water Spectrum, v. 7, no. 2 , p. 41-46.

King, N. J., 1974, Occurrence of ground water in the Gillette area, Campbell County, Wyoming: U.S. Geo1. Survey Misc. Inv. Map I-848-E, 1 sheet.

Konikow, L. F., 1975, Preliminary digital model of ground-water flow in the Madison Group, Powder River Basin and adjacent areas, Wyoming, Montana, South Dakota, North Dakota, and Nebraska: U.S. Geol. Survey Water-Resources Inv. 63-75, 44 p., 6 pl.

Littleton, R. L., 1950, Ground-water conditions in the vicinity of Gillette, Wyoming, with a section on the Quality of ground water, by H. A. Swenson: U.S. Geol. Survey Circ. 76, 43 p.

Lowham, H. W., Kircher, J. E., and Boner, F. C., 1975, Temperatures of Wyoming streams: Wyoming State Engineer, Wyoming Water Plan. rept. no. 15,115 p.

Lowry, M. E., 1973, Hydrology of the uppermost Cretaceous and lowermost Paleocene rocks in the Hilight oil field, Campbell County, Wyoming: U.S. Geol. Survey open-file rept., 60 p., 5 pl.

Lowry, M. E., and Cummings, T. R., 1966, Ground-water resources of Sheridan County, Wyoming: U.S. Geol. Survey Water-Supply Paper 1807, 73 p.

Northern Great Plains Resources Program, 1974, Shallow ground water in selected areas in the Fort Union coal region: U.S. Geol. Survey open-file rept. $74-371,72$ p., 12 tables, 18 figs.

0'Conne11, D. J., 1969, Surface-water discharge and ground-water 1evels in the East Fork River area, Sublette County, Wyoming: U.S. Geol. Survey open-file rept., 77 p.

Price, Don, and Arnow, Ted, 1974, Summary appraisals of the Nation's ground-water resources--Upper Colorado Region: U.S. Geol. Survey Prof. Paper 813-C, 40 p., 2 pl. 
Price, Don, and Waddell, K. M., 1973, Selected hydrologic data in the Upper Colorado River basin: U.S. Geol. Survey Hydrol. Inv. Atlas HA-477, 2 sheets.

Rennick, R. B., 1966, Floods of May-June, 1965, in east-central Wyoming: U.S. Geol. Survey open-file rept., 22 p.

Ringen, B. H., 1973, Records of ground-water levels in Wyoming, 1940-1971: Wyoming State Engineer, Wyoming Water Plan. Program rept. no. 13, 479 p.

1974, Ground-water levels in Wyoming, 1972-1973: Wyoming State Englneer, Wyoming Water Plan. Program rept. no. 13, supp1. no. 1, $158 \mathrm{p}$.

Robinove, C. J., and Cummings, T. R., 1963, Ground-water resources and geology of the Lyman-Mountain View area, Uinta County, Wyoming: U.S. Geol. Survey Water-Supply Paper 1669-E, 43 p.

Swenson, F. A., 1974, Possible development of water from Madison Group and associated rocks in Powder River Basin, Montana-Wyoming: Northern Great Plains Resources Program rept., 6 p., 1 table, 4 p1.

Swenson, F. A., Hodson, W. G., Miller, W. R., and Visher, F. N., 1975, Water in the Madison Group, Powder River, Wyoming and Montana: U.S. Geo1. Survey open-file rept. $75-660,4$ sheets (in press as U.S. Geo1. Survey Misc. Inv. Map I-847-C).

U.S. Geological Survey, Water resources data for Wyoming--Part 1, Surface water records; Part 2, Water quality records, 1965-1974 (published annually): U.S. Geol. Survey open-file repts. (For information about records prior to 1965 , contact nearest USGS office.)

1975, Plan of study of the hydrology of the Madison Limestone and associated rocks in parts of Montana, Nebraska, North Dakota, South Dakota, and Wyoming: U.S. Geol. Survey open-file rept. 75-631, 35 p., 2 tables.

Warner, D. A., 1946, Geology and ground-water resources of the Ranchester area, Wyoming: U.S. Geol. Survey open-file rept., 11 p.

Welder, G. E., 1968, Ground-water reconnaissance of the Green River basin, southwestern Wyoming: U.S. Geo1. Survey Hydrol. Inv. Atlas HA-290, 2 sheets.

Welder, G. E., and McGreevey, L. J., 1966, Ground-water reconnaissance of the Great Divide and Washakie basins and some adjacent areas, southwestern Wyoming: U.S. Geo1. Survey Hydrol. Inv. Atlas HA-219, 3 sheets. 
Whitcomb, H. A., 1960, Investigation of declining artesian pressures in the vicinity of Osage, Weston County, Wyoming: U.S. Geol. Survey open-file rept., 11 p., 1 fig.

1963, Decreasing yields of flowing wells in the vicinity of Newcastle, Weston County, Wyoming: U.S. Geol. Survey open-file rept., 22 p., 1 fig.

1965, Ground-water resources and geology of Niobrara County, Wyoming, with a section on the hemical quality of the ground water, by T. R. Cummings: U.S. Geo1. Survey Water-Supply Paper 1788, 97 p.

Whitcomb, H. A., Cummings, T. R., and McCollough, R. A., 1966, Groundwater resources and geology of northern and central Johnson County, Wyoming: U.S. Geol. Survey Water-Supply Paper 1806, 99 p.

Whitcomb, H. A., and Gordon, E. D., 1964, Availability of ground water at Devils Tower National Monument, Wyoming: U.S. Geo1. Survey openfile rept., 61 p., 7 figs.

Whitcomb, H. A., and Morris, D. A., 1964, Ground-water resources and geology of northern and western Crook County, Wyoming, with a section on the Chemical quality of the ground water, by R. H. Langford:

U. S. Geol. Survey Water-Supply Paper 1698, 92 p.

Whitcomb, H. A., Morris, D. A., Gordon, E. D., and Robinove, C. J., 1958, Occurrence of ground water in the eastern Powder River basin and western Black Hills, northeastern Wyoming, in Wyoming Geol. Assoc. Guidebook 13th Ann. Field Conf., Powder River basin, 1958, p. 245-260.

Williams, C. C., 1948, Water-supply possibilities from wells at Newcastle, Wyoming: U.S. Geol. Survey open-file rept., 19 p. 


